\title{
A Near IR Fluorescent Probe for Enantioselective Recognition of Amino Acids in Aqueous Solution
}

Feng Zhao ${ }^{\mathrm{a}, \mathrm{b}}$, Jun Tian ${ }^{\mathrm{a}}$, Xuedan $\mathrm{Wu}^{\mathrm{b}}$, Shuo Li ${ }^{\mathrm{b}, \mathrm{c}}$, Yu Chen ${ }^{\mathrm{a}}$, Shanshan Yu*a , Xiaoqi Yu*a Lin Pu*b

\section{Table of Content}

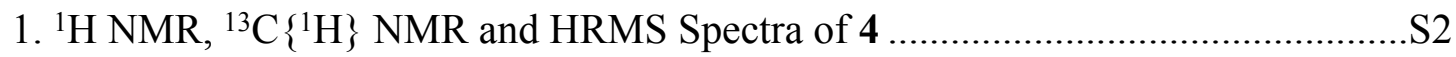

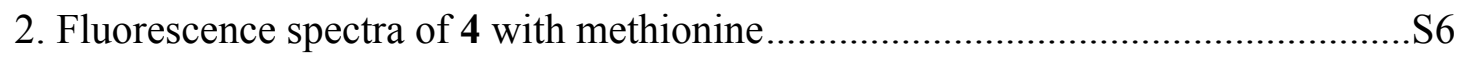

3. Fluorescence spectra of $(R)-4$ with amino acids .............................................. 11

4. NMR and Mass spectroscopic studies of the reactions......................................S24

5. Photographs of $(R)-4$ and $\mathrm{ZnBr}_{2}$ with D- or L-amino acids...............................S28

6. Fluorescence spectra of (R)-4 with D-Met or L-Met in the presence of $\mathrm{Zn}^{2+}$ salts of various counter anions S29 


\section{1. ${ }^{1} \mathrm{H}$ NMR, ${ }^{13} \mathrm{C}\left\{{ }^{1} \mathrm{H}\right\}$ NMR and HRMS Spectra of 4}

${ }^{1} \mathrm{H}$ NMR $(600 \mathrm{MHz})$ spectra of $(R)-4$ in DMSO- $d_{6}$

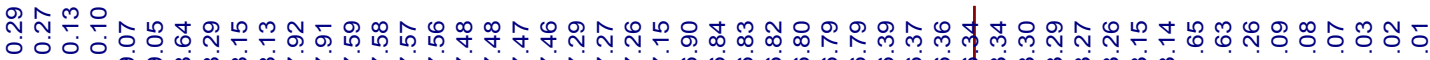
응응요

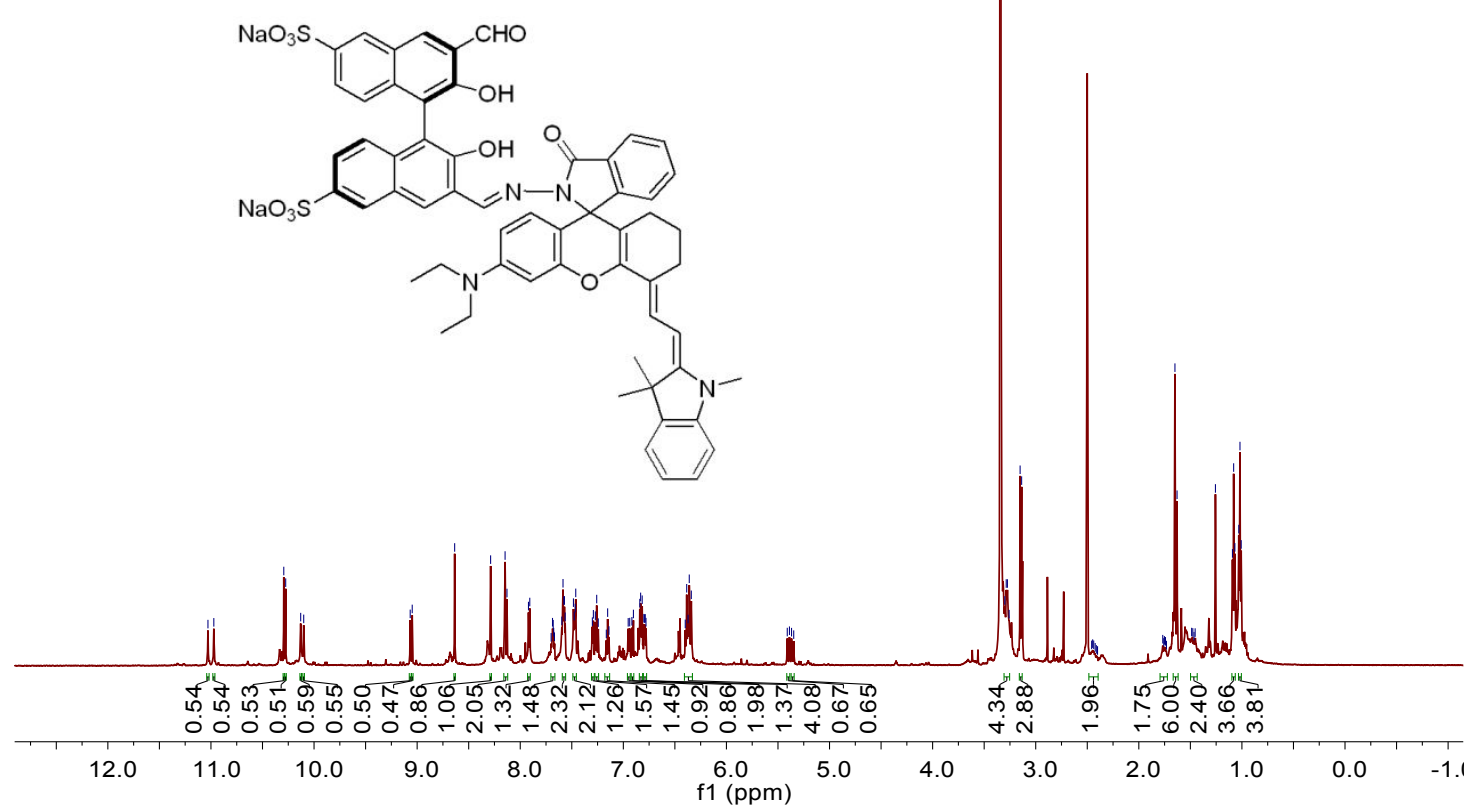

${ }^{13} \mathrm{C}\left\{{ }^{1} \mathrm{H}\right\}$ NMR (201 MHz) spectra of $(R)-4$ in DMSO- $d_{6}$

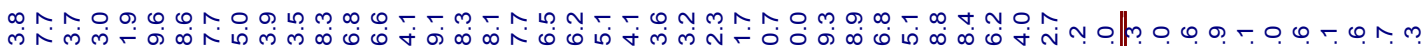

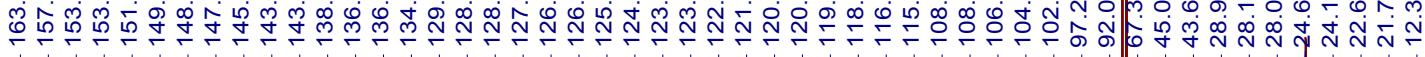

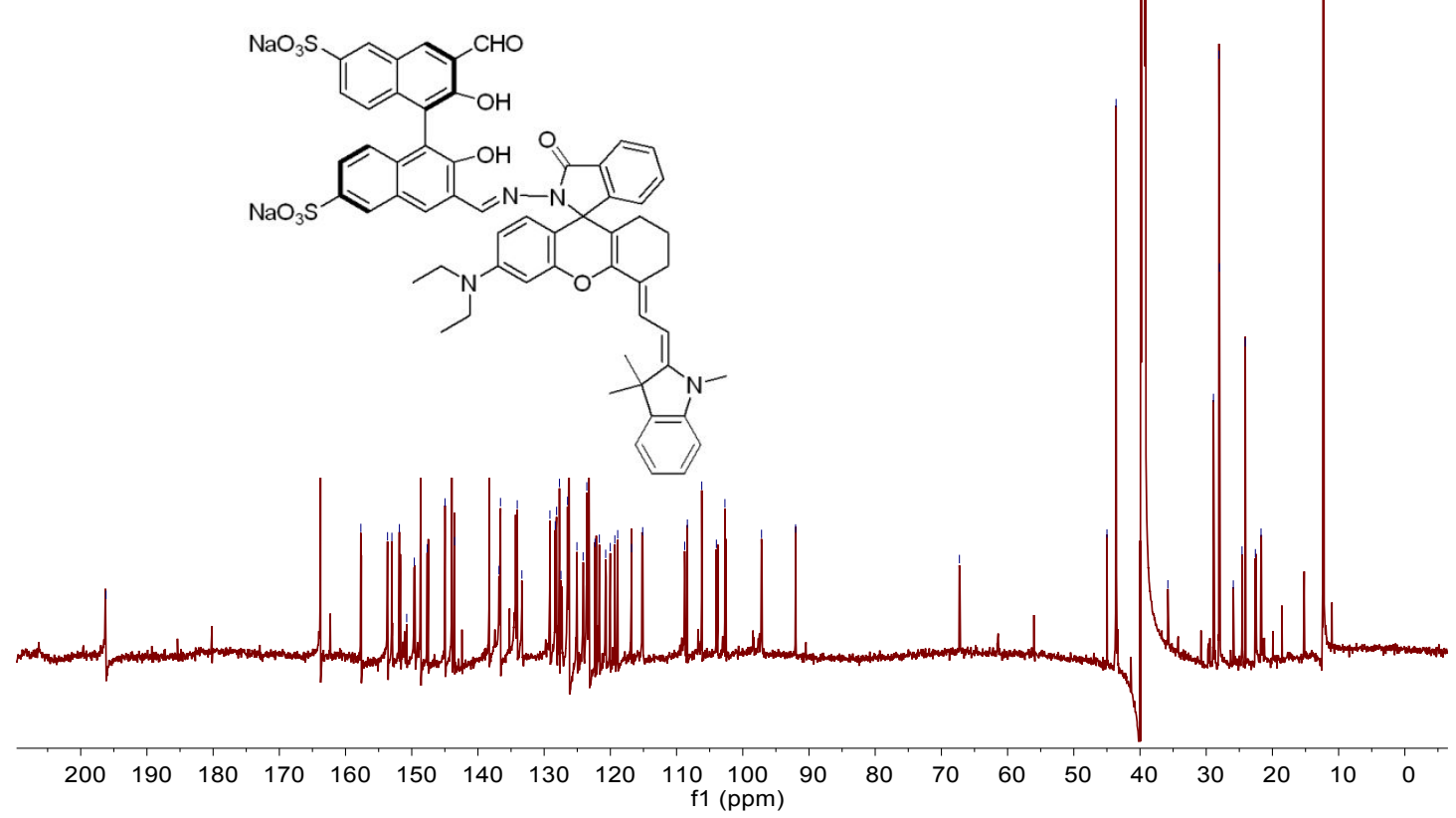


${ }^{1} \mathrm{H}$ NMR $(600 \mathrm{MHz})$ spectra of $(S)-4$ in DMSO- $d_{6}$

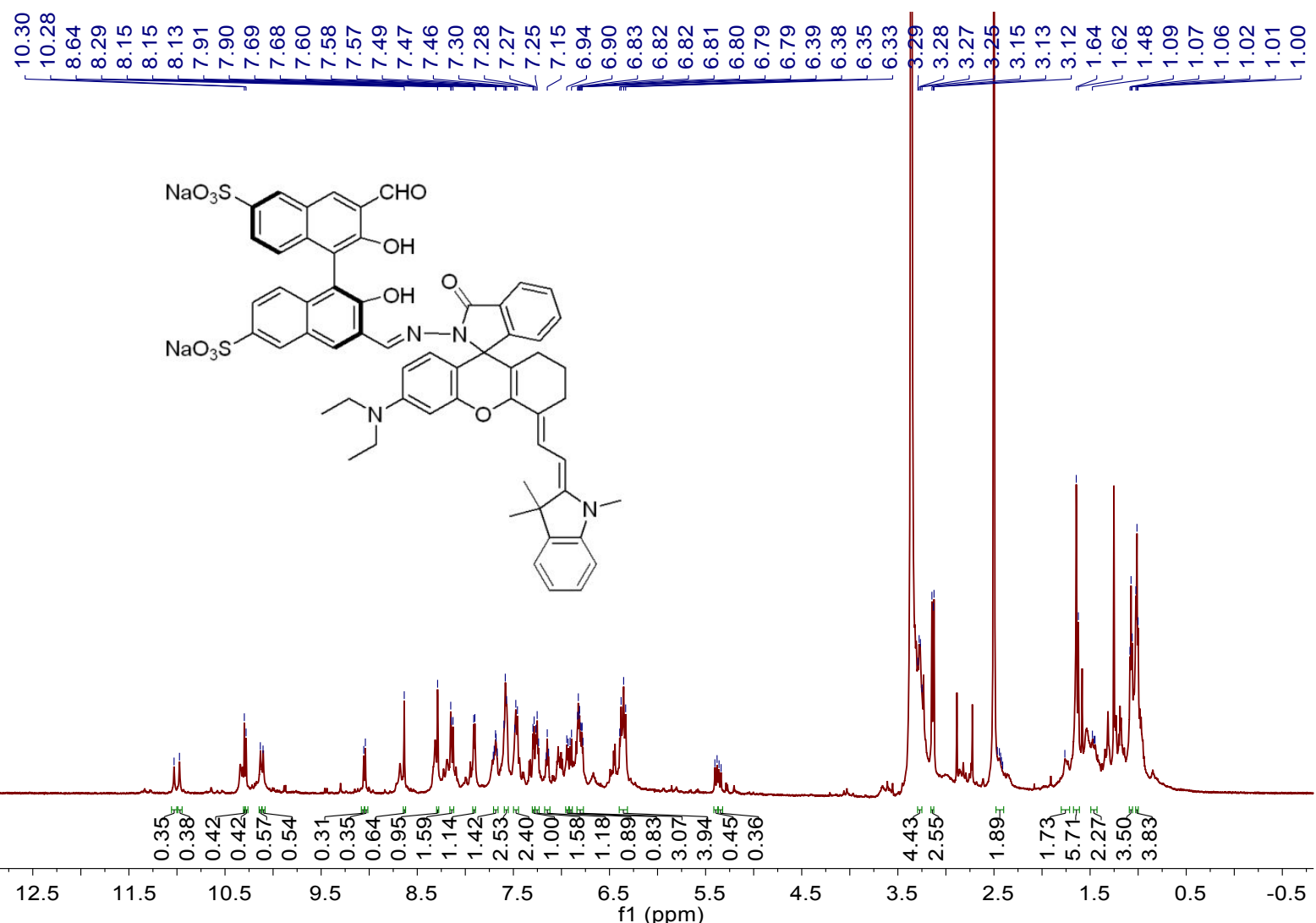

${ }^{13} \mathrm{C}\left\{{ }^{1} \mathrm{H}\right\}$ NMR (201 MHz) spectra of $(S)-4$ in DMSO- $d_{6}$

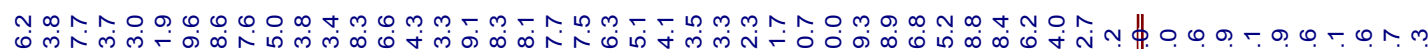

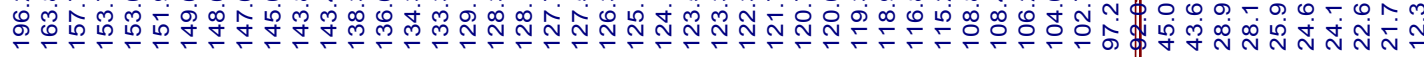

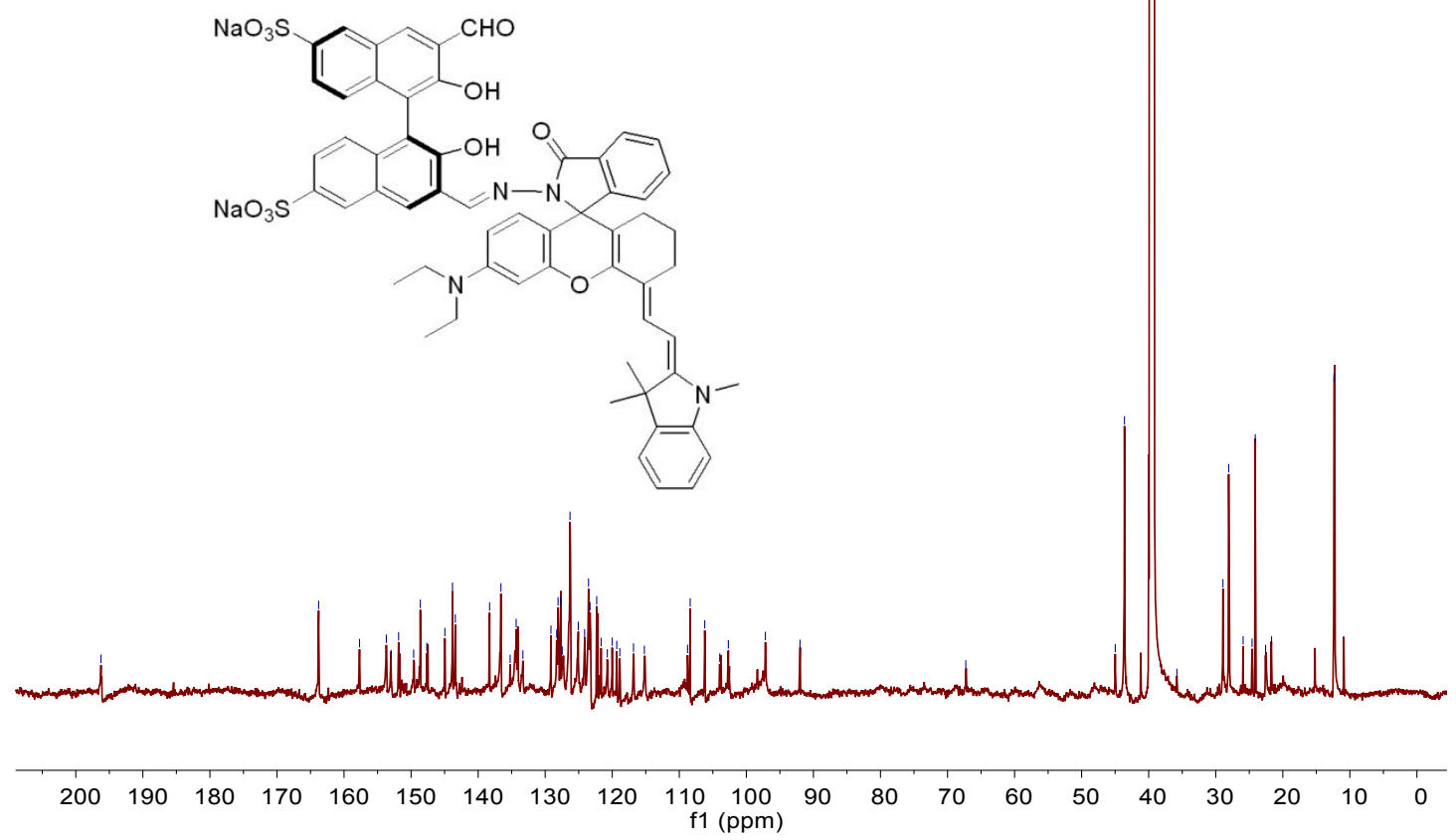


HRMS of $(R)-4$

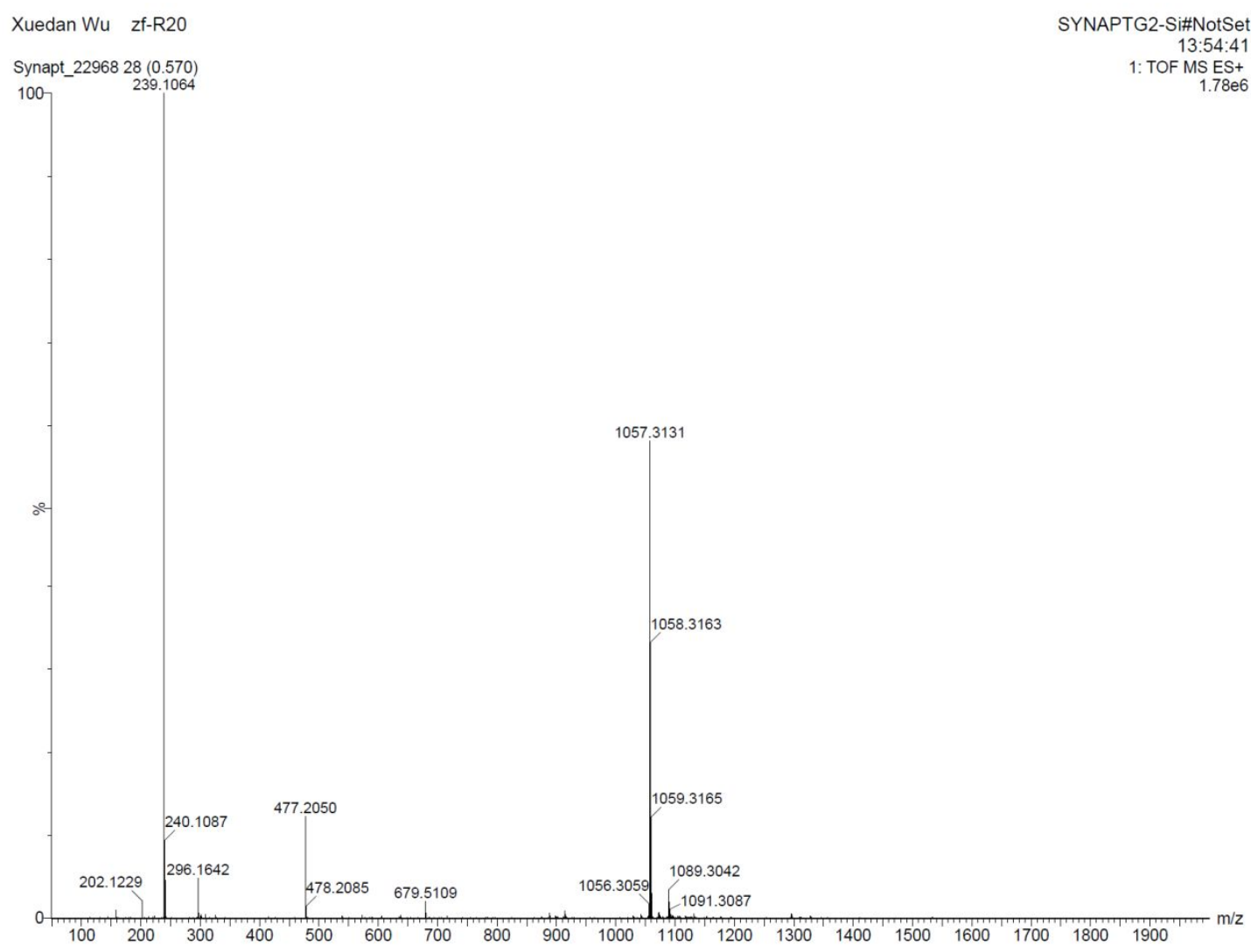

HRMS of (S)-4

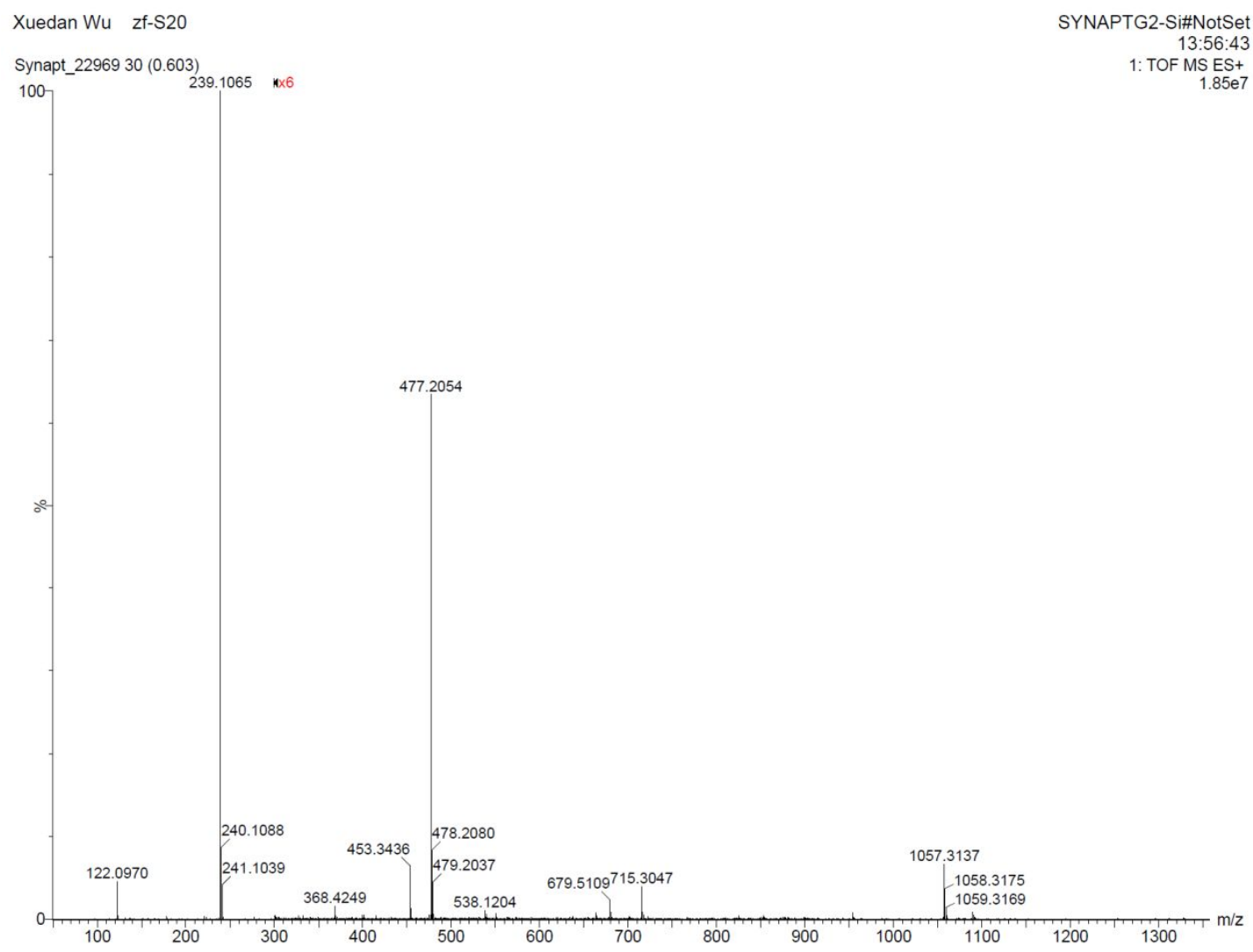


Figure S1. Structures of amino acids studied.<smiles>CC(N)C(=O)O</smiles>

Ala<smiles>NC(N)NCCCC(N)C(=O)O</smiles>

Arg<smiles>NC(=O)CC(N)C(=O)O</smiles>

Asn<smiles>N[C@@H](CC(=O)O)C(=O)O</smiles>

Asp<smiles>NC(CS)C(=O)O</smiles>

Cys<smiles>NC(=O)CCC(N)C(=O)O</smiles>

Gln<smiles>N[C@@H](CCC(=O)O)C(=O)O</smiles>

Glu<smiles>NC(Cc1c[nH]cn1)C(=O)O</smiles>

His<smiles>CC(C)CC(N)C(=O)O</smiles>

Leu<smiles>NCCCCC(N)C(=O)O</smiles>

Lys<smiles>CC(O)C(N)C(=O)O</smiles>

Thr<smiles>CSCCC(N)C(=O)O</smiles>

Met<smiles>NC(Cc1c[nH]c2ccccc12)C(=O)O</smiles>

Trp<smiles>NC(Cc1ccccc1)C(=O)O</smiles>

Phe<smiles>O=C(O)C1CCCN1</smiles>

Pro<smiles>NC(CO)C(=O)O</smiles>

Ser<smiles>CC(C)C(N)C(=O)O</smiles> 


\section{Fluorescence spectra of $\mathbf{4}$ with methionine}

Figure S2. Fluorescence spectra of $(R)-4+\mathrm{Zn}^{2+}(2$ equiv) $(10 \mu \mathrm{M})$ with various equiv of D-Met or L-Met in $50 \mathrm{mM}$ HEPES $(\mathrm{pH}=7.4) / 1 \%$ DMSO. Fluorescence intensity at $736 \mathrm{~nm}$ versus the equiv of methionine. Spectra were recorded at $\mathrm{rt}$ after mixing at $37^{\circ} \mathrm{C}$ for $4 \mathrm{~h} .\left(\lambda_{\mathrm{exc}}=690 \mathrm{~nm}\right.$, slits $\left.=5 / 5 \mathrm{~nm}\right)$
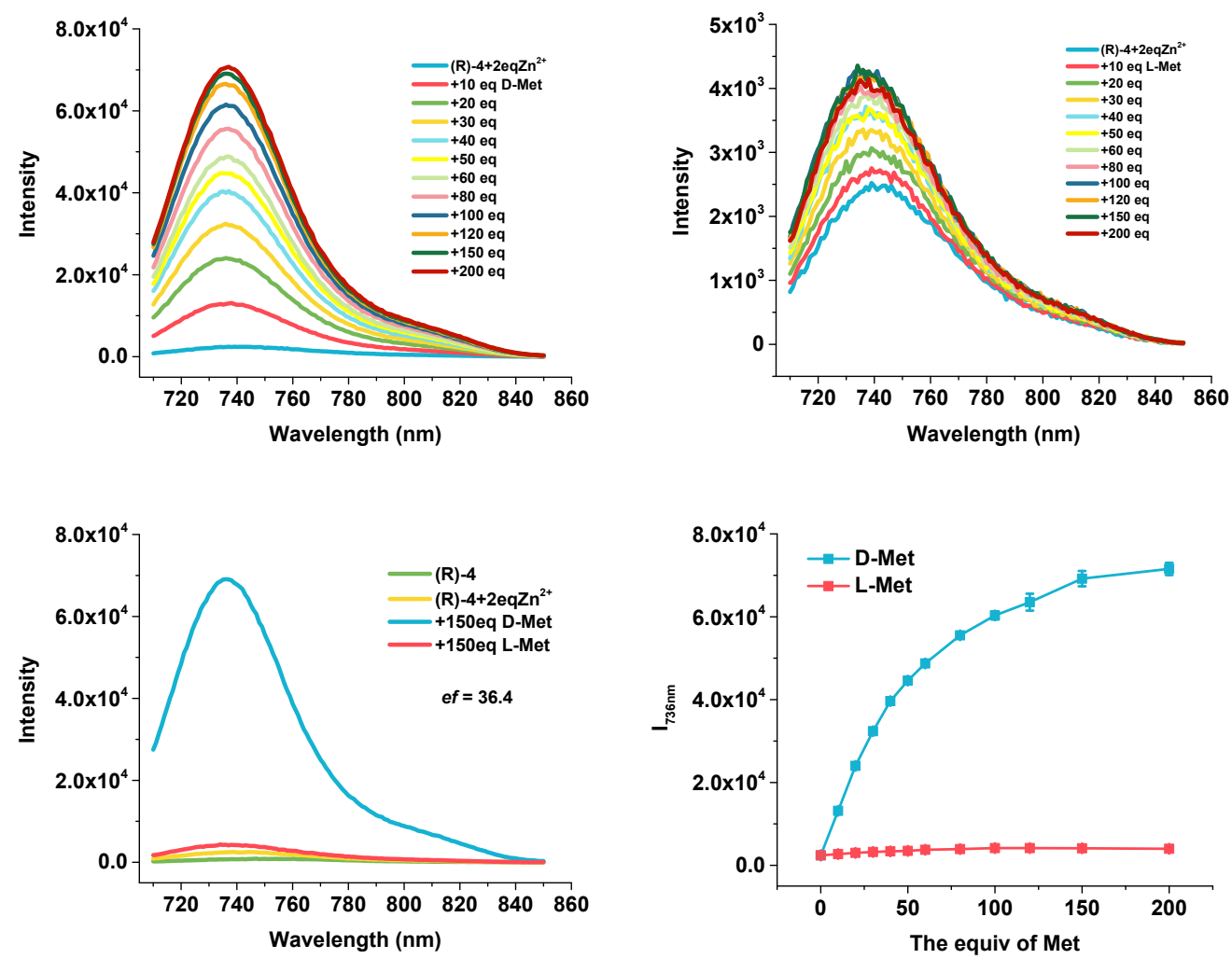
Figure S3. Fluorescence spectra of $(S)-4+\mathrm{Zn}^{2+}$ (2 equiv) $(10 \mu \mathrm{M})$ with various equiv of D-Met or L-Met in $50 \mathrm{mM}$ HEPES $(\mathrm{pH}=7.4) / 1 \%$ DMSO. Fluorescence intensity at $736 \mathrm{~nm}$ versus the equiv of methionine. Spectra were recorded at $\mathrm{rt}$ after mixing at $37^{\circ} \mathrm{C}$ for $4 \mathrm{~h} .\left(\lambda_{\text {exc }}=690 \mathrm{~nm}\right.$, slits $\left.=5 / 5 \mathrm{~nm}\right)$
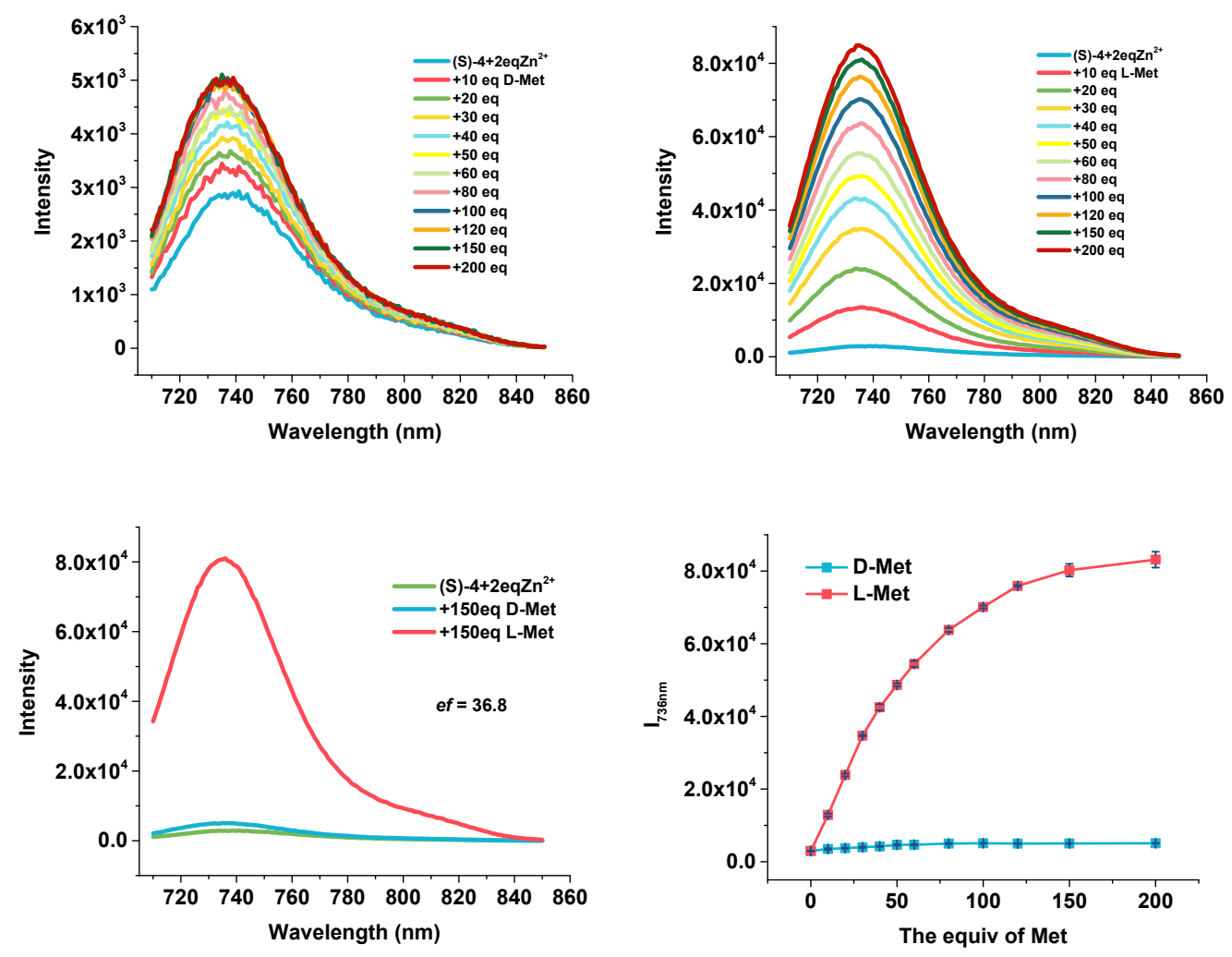
Figure S4. Fluorescence spectra of $(R)-4$ and $(S)-4(10 \mu \mathrm{M})+\mathrm{Zn}^{2+}(2$ equiv $)\left(1.0 \times 10^{-}\right.$ ${ }^{5} \mathrm{M}$ ) in the presence of the enantiomeric mixture of methionine (150 equiv) [from $0 \%$ to $100 \%$ D-Met]. Fluorescence intensity at $736 \mathrm{~nm}$ versus the enantiomeric purity of methionine. Spectra were recorded at $\mathrm{rt}$ after mixing at $37^{\circ} \mathrm{C}$ for $4 \mathrm{~h}$. $\left(\lambda_{\mathrm{exc}}=690 \mathrm{~nm}\right.$, slits $=5 / 5 \mathrm{~nm})$
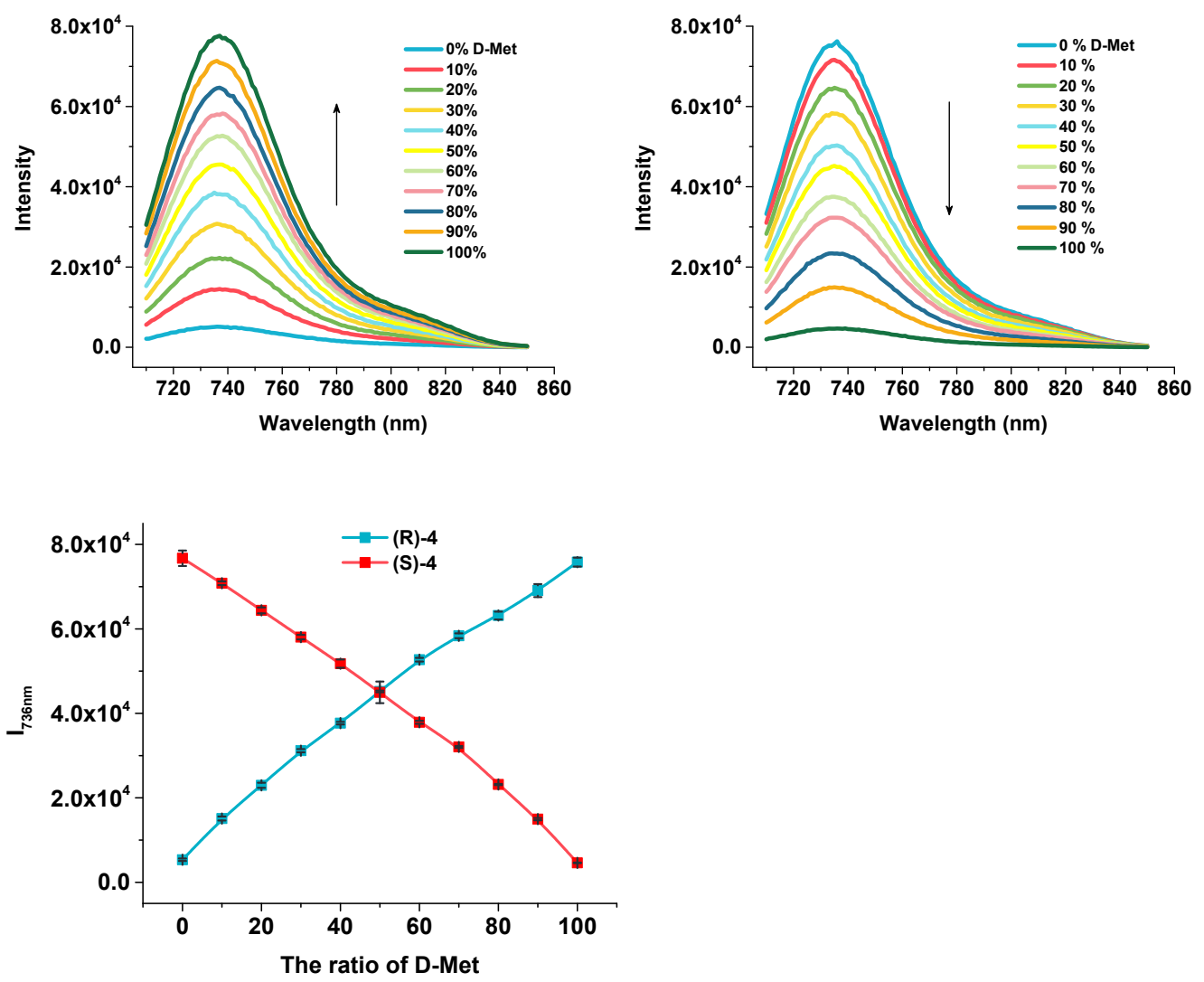
Figure S5. Fluorescence spectra of $(R)-4\left(1.0 \times 10^{-5} \mathrm{M}\right)$ with various equiv of $\mathrm{Zn}^{2+}$ in $50 \mathrm{mM}$ HEPES buffer $(\mathrm{pH}=7.4) / 1 \%$ DMSO in the presence of 150 equiv of D-Met or L-Met. Fluorescence intensity at $736 \mathrm{~nm}$ versus the equiv of $\mathrm{Zn}(\mathrm{OAc})_{2}$. Spectra were recorded at $\mathrm{rt}$ after mixing at $37^{\circ} \mathrm{C}$ for $4 \mathrm{~h} . \quad\left(\lambda_{\mathrm{exc}}=690 \mathrm{~nm}\right.$, slits $\left.=5 / 5 \mathrm{~nm}\right)$
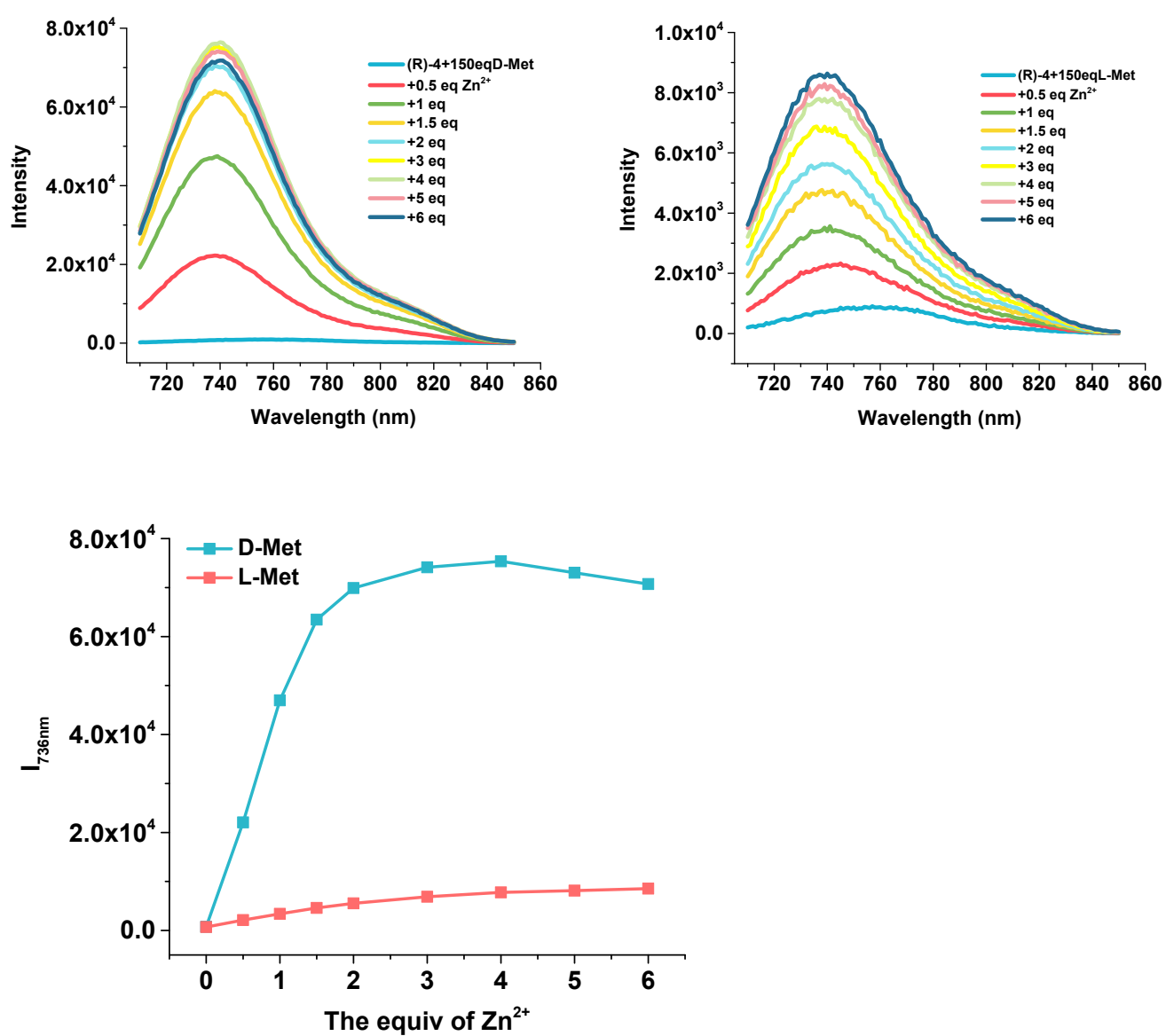
Figure S6. Time dependence fluorescence responses. $(R)-4\left(1.0 \times 10^{-5} \mathrm{M}\right.$ in $50 \mathrm{mM}$ HEPES at $\mathrm{pH}=7.4 / 1 \% \mathrm{DMSO}$ ) and $\mathrm{Zn}^{2+}$ (2 equiv) were placed in a $10 \mathrm{~mL}$ test tube, to which was added $\mathrm{D}$ - or L- Met (150 equiv). The resulting solutions were allowed to stand at $37^{\circ} \mathrm{C}$ for $10,20,40,60,80,100,120,150,180,210,240,270,300$ and 330 min respectively and each fluorescent spectrum was recorded at rt. This figure plots the fluorescent intensities at $736 \mathrm{~nm}$ versus the reaction time. $\quad\left(\lambda_{\text {exc }}=690 \mathrm{~nm}\right.$, slits $=$ $5 / 5 \mathrm{~nm})$

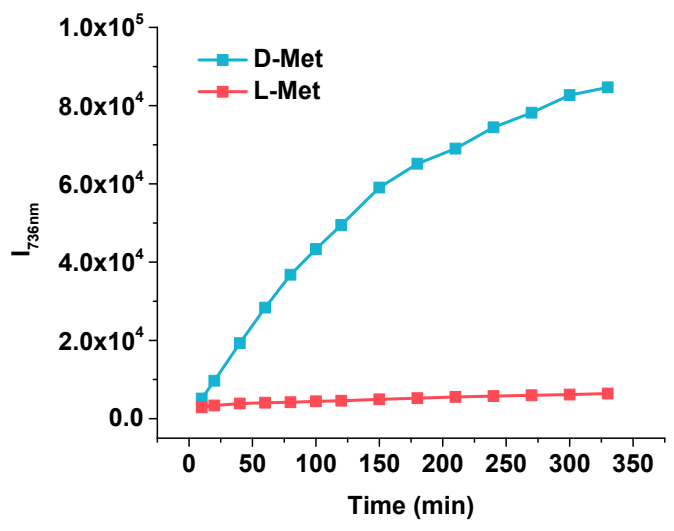




\section{Fluorescence spectra of $(R)-4$ with amino acids}

Figure S7. Fluorescence spectra of $(R)-4(10 \mu \mathrm{M})+\mathrm{Zn}^{2+}$ (2 equiv) with various equiv of D- or L-Ala in $50 \mathrm{mM}$ HEPES $(\mathrm{pH}=7.4) / 1 \%$ DMSO. Fluorescence intensity at $736 \mathrm{~nm}$ versus the equiv of alanine. Spectra were recorded at $\mathrm{rt}$ after mixing at $37^{\circ} \mathrm{C}$ for $4 \mathrm{~h} .\left(\lambda_{\mathrm{exc}}=690 \mathrm{~nm}\right.$, slits $\left.=5 / 5 \mathrm{~nm}\right)$
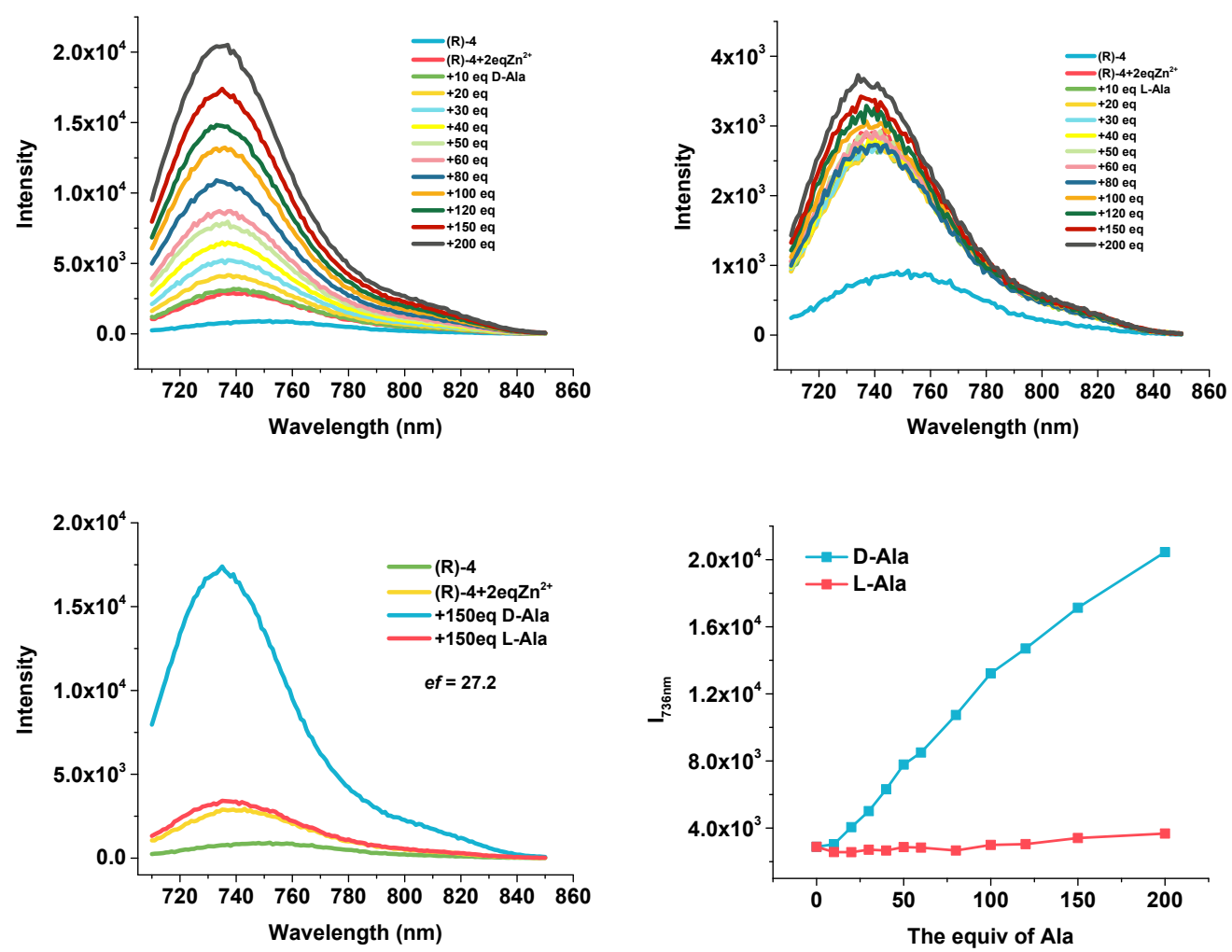

Figure S8. Fluorescence spectra of $(R)-4(10 \mu \mathrm{M})+\mathrm{Zn}^{2+}(2$ equiv $)$ with various equiv of D-Arg or L-Arg in $50 \mathrm{mM}$ HEPES $(\mathrm{pH}=7.4) / 1 \%$ DMSO. Fluorescence intensity at $736 \mathrm{~nm}$ versus the equiv of arginine. Spectra were recorded at $\mathrm{rt}$ after mixing at 37 ${ }^{\circ} \mathrm{C}$ for $4 \mathrm{~h} .\left(\lambda_{\text {exc }}=690 \mathrm{~nm}\right.$, slits $\left.=5 / 5 \mathrm{~nm}\right)$
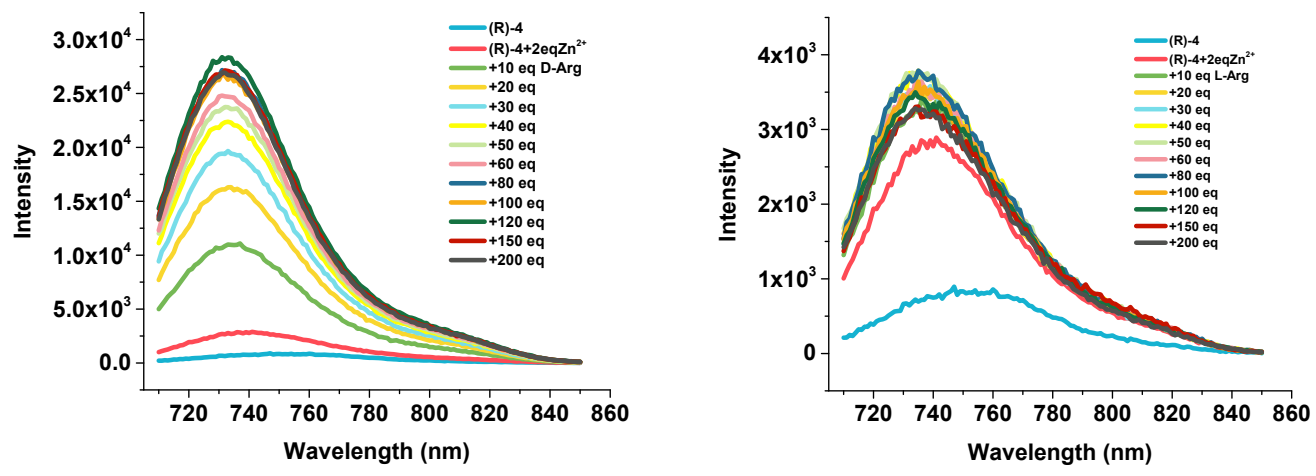

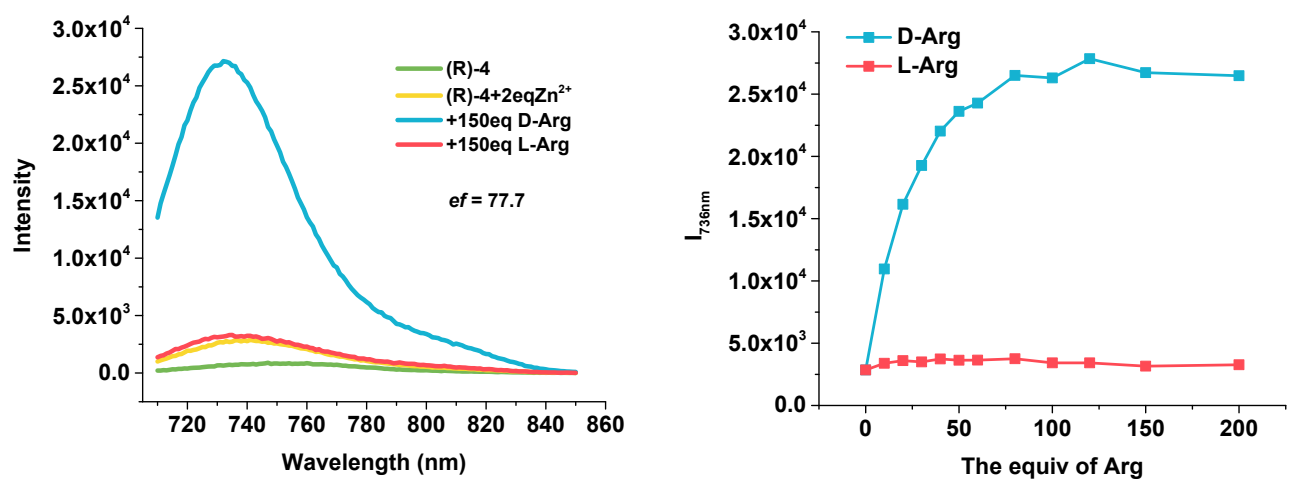
Figure S9. Fluorescence spectra of $(R)-4(10 \mu \mathrm{M})+\mathrm{Zn}^{2+}$ (2 equiv) with various equiv of D-Asn or L-Asn in $50 \mathrm{mM}$ HEPES $(\mathrm{pH}=7.4) / 1 \%$ DMSO. Fluorescence intensity at $736 \mathrm{~nm}$ versus the equiv of Asparagine. Spectra were recorded at $\mathrm{rt}$ after mixing at $37^{\circ} \mathrm{C}$ for $4 \mathrm{~h} .\left(\lambda_{\mathrm{exc}}=690 \mathrm{~nm}\right.$, slits $\left.=5 / 5 \mathrm{~nm}\right)$
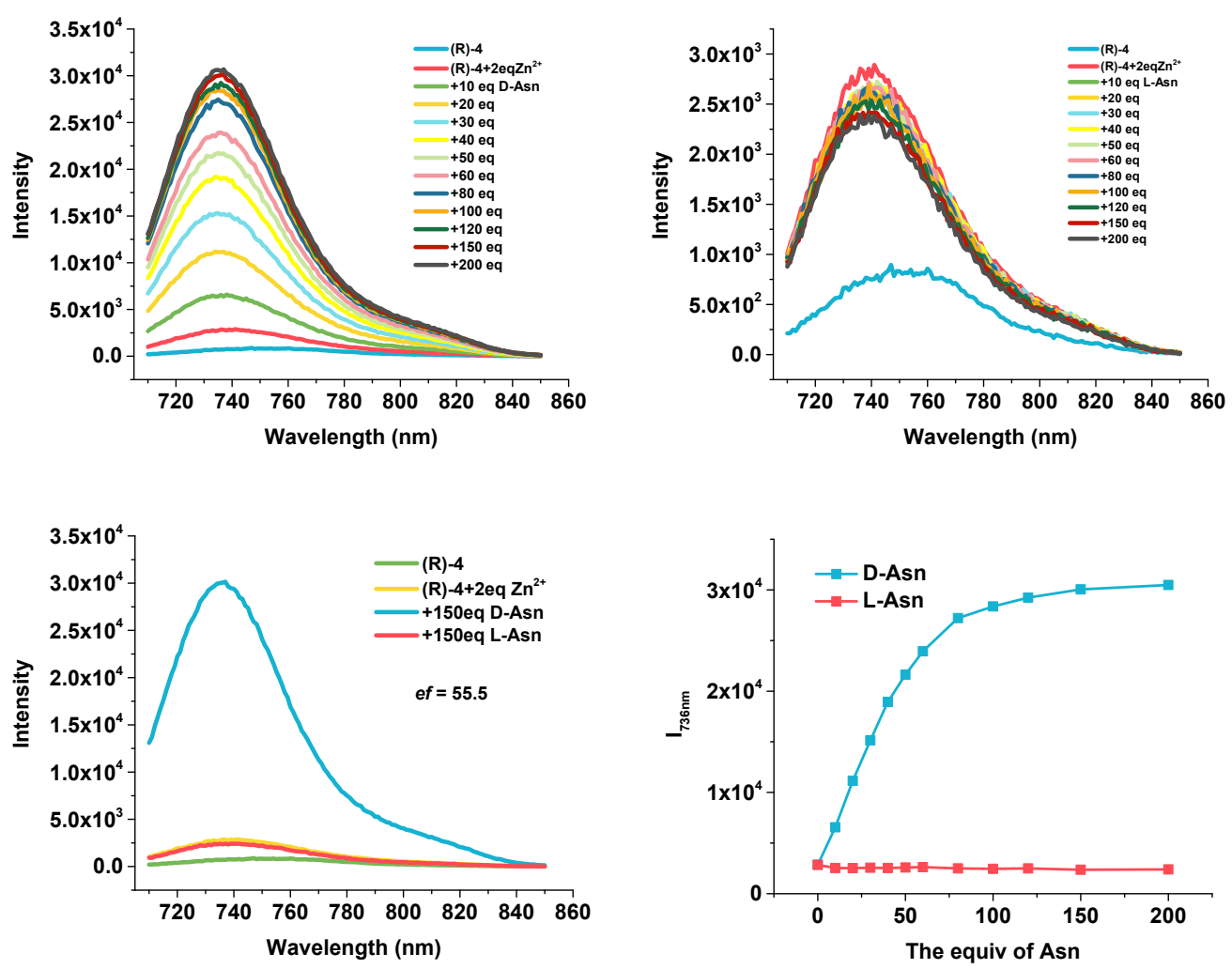
Figure S10. Fluorescence spectra of $(R)-4(10 \mu \mathrm{M})+\mathrm{Zn}^{2+}(2$ equiv $)$ with various equiv of D-Gln or L-Gln in $50 \mathrm{mM}$ HEPES $(\mathrm{pH}=7.4) / 1 \%$ DMSO. Fluorescence intensity at $736 \mathrm{~nm}$ versus the equiv of glutamine. Spectra were recorded at $\mathrm{rt}$ after mixing at $37^{\circ} \mathrm{C}$ for $4 \mathrm{~h} .\left(\lambda_{\mathrm{exc}}=690 \mathrm{~nm}\right.$, slits $\left.=5 / 5 \mathrm{~nm}\right)$
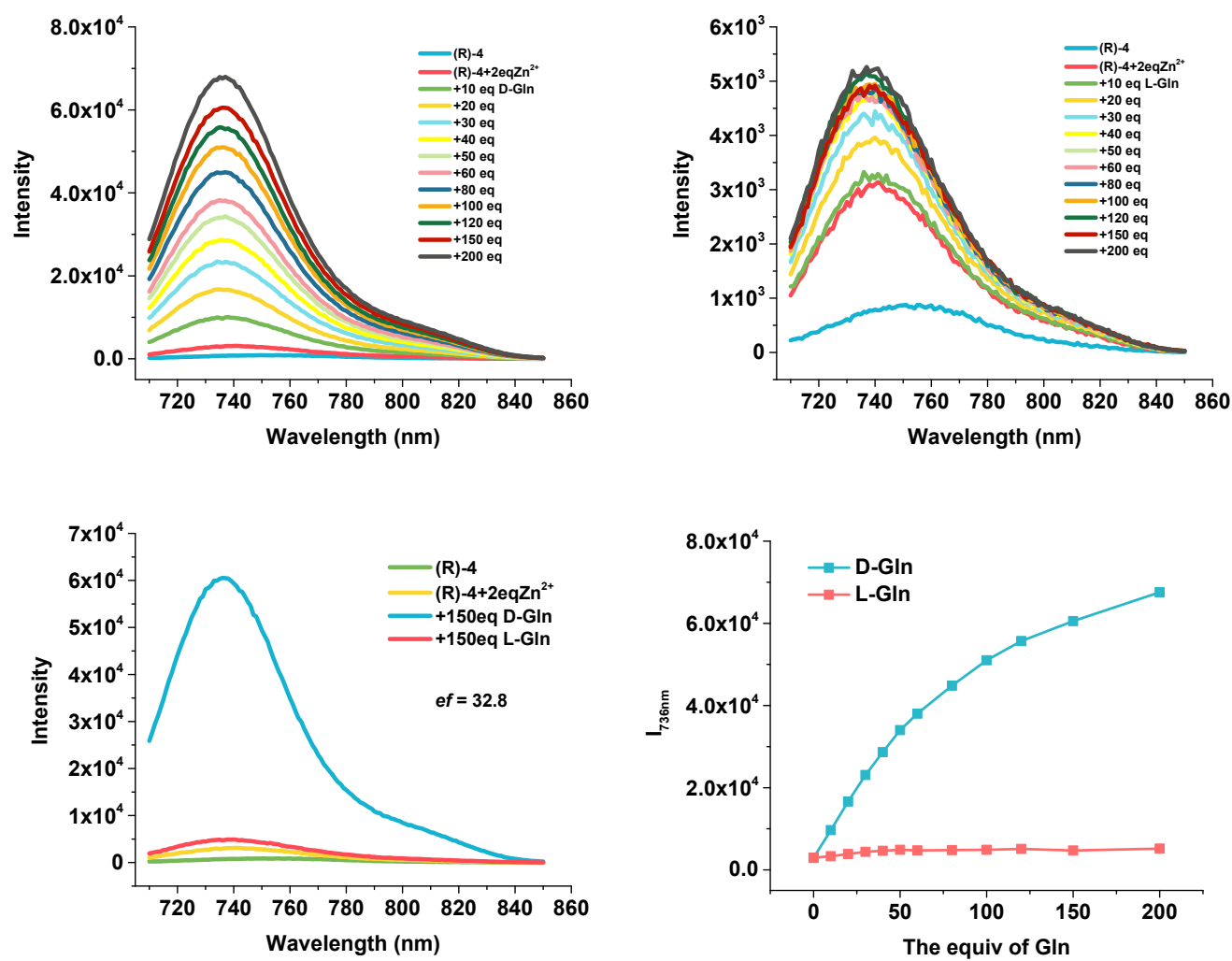
Figure S11. Fluorescence spectra of $(R)-4(10 \mu \mathrm{M})+\mathrm{Zn}^{2+}(2$ equiv) with various equiv of D-His or L-His in $50 \mathrm{mM}$ HEPES $(\mathrm{pH}=7.4) / 1 \%$ DMSO. Fluorescence intensity at $736 \mathrm{~nm}$ versus the equiv of histidine. Spectra were recorded at $\mathrm{rt}$ after mixing at $37^{\circ} \mathrm{C}$ for $4 \mathrm{~h} .\left(\lambda_{\mathrm{exc}}=690 \mathrm{~nm}\right.$, slits $\left.=5 / 5 \mathrm{~nm}\right)$
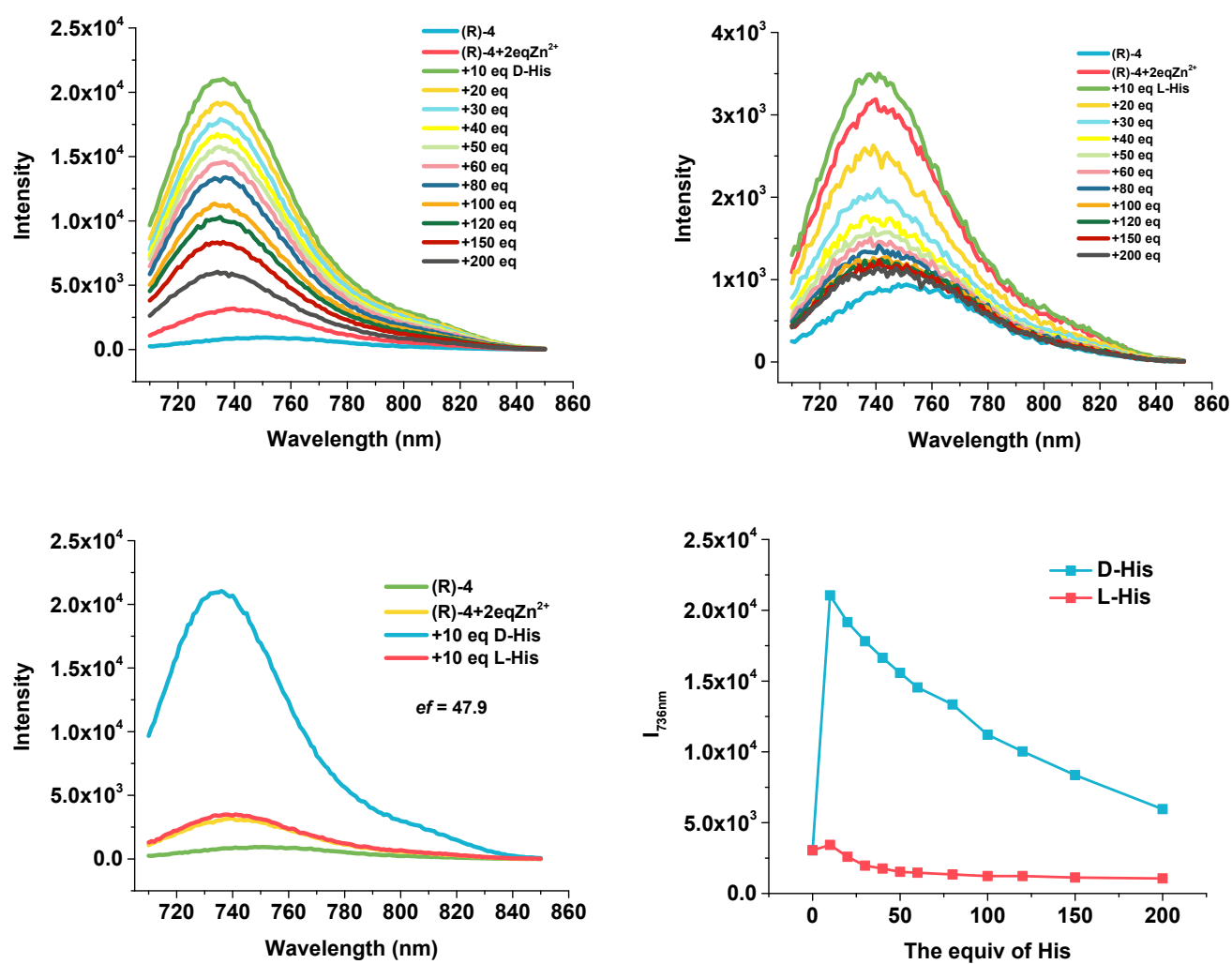
Figure S12. Fluorescence spectra of $(R)-4(10 \mu \mathrm{M})+\mathrm{Zn}^{2+}$ (2 equiv) with various equiv of D-Leu or L-Leu in $50 \mathrm{mM}$ HEPES $(\mathrm{pH}=7.4) / 1 \%$ DMSO. Fluorescence intensity at $736 \mathrm{~nm}$ versus the equiv of Leucine. Spectra were recorded at rt after mixing at $37^{\circ} \mathrm{C}$ for $4 \mathrm{~h} .\left(\lambda_{\text {exc }}=690 \mathrm{~nm}\right.$, slits $\left.=5 / 5 \mathrm{~nm}\right)$
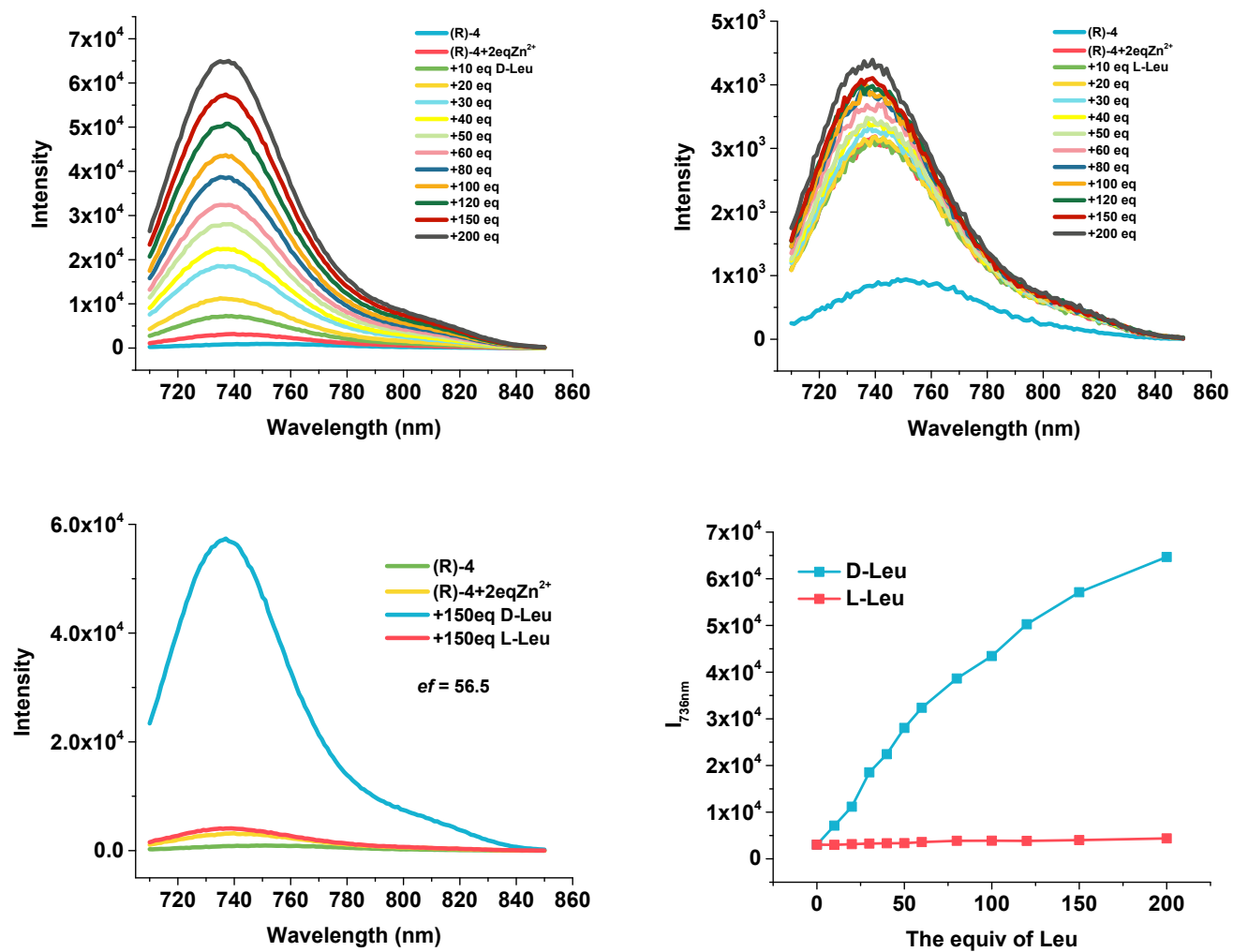
Figure S13. Fluorescence spectra of $(R)-4(10 \mu \mathrm{M})+\mathrm{Zn}^{2+}$ (2 equiv) with various equiv of D-Lys or L-Lys in $50 \mathrm{mM}$ HEPES $(\mathrm{pH}=7.4) / 1 \%$ DMSO. Fluorescence intensity at $736 \mathrm{~nm}$ versus the equiv of Lysine. Spectra were recorded at $\mathrm{rt}$ after mixing at $37^{\circ} \mathrm{C}$ for $4 \mathrm{~h} .\left(\lambda_{\text {exc }}=690 \mathrm{~nm}\right.$, slits $\left.=5 / 5 \mathrm{~nm}\right)$
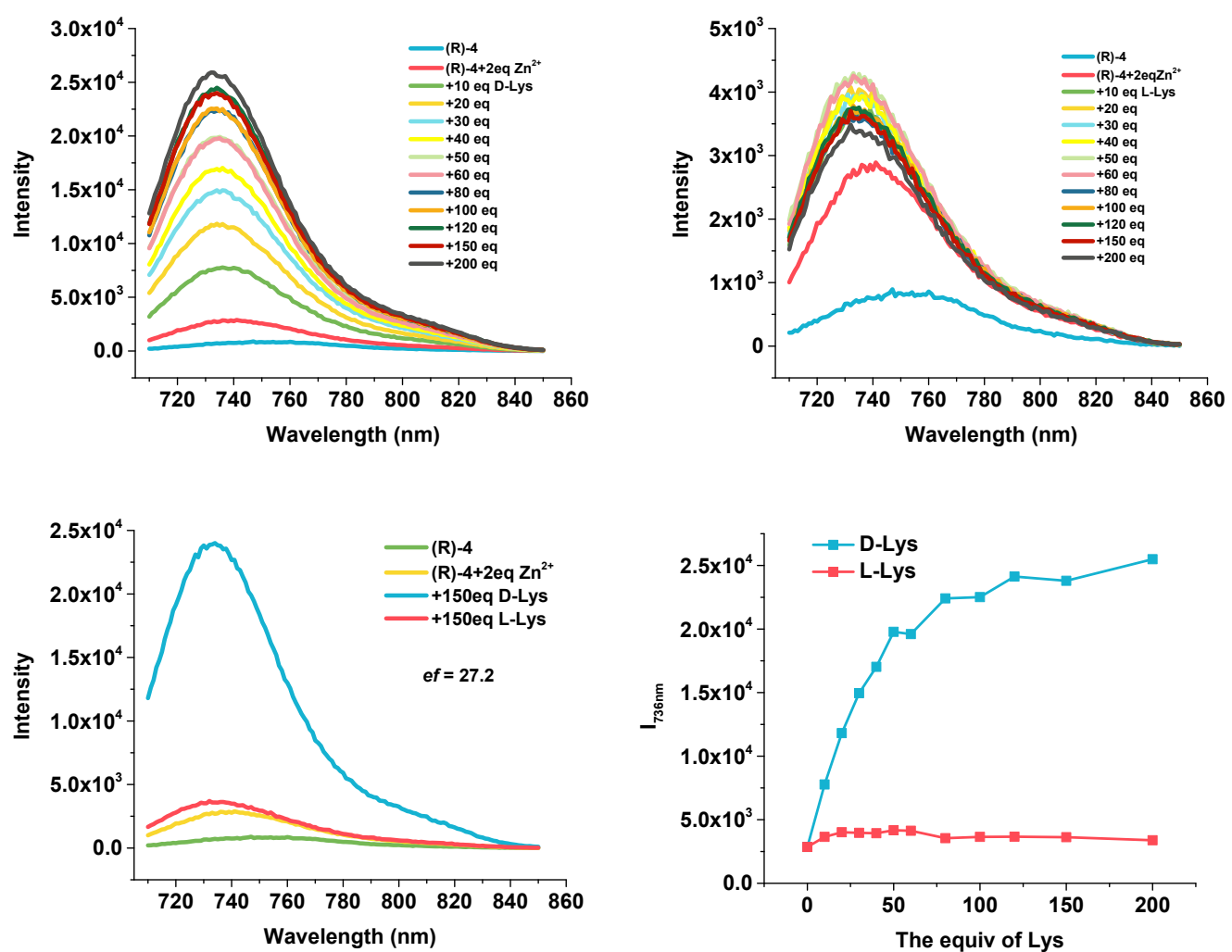
Figure S14. Fluorescence spectra of $(R)-4(10 \mu \mathrm{M})+\mathrm{Zn}^{2+}$ (2 equiv) with various equiv of D-Phe or L-Phe in $50 \mathrm{mM}$ HEPES $(\mathrm{pH}=7.4) / 1 \%$ DMSO. Fluorescence intensity at $736 \mathrm{~nm}$ versus the equiv of phenylalanine. Spectra were recorded at $\mathrm{rt}$ after mixing at $37^{\circ} \mathrm{C}$ for $4 \mathrm{~h}$. $\left(\lambda_{\mathrm{exc}}=690 \mathrm{~nm}\right.$, slits $\left.=5 / 5 \mathrm{~nm}\right)$
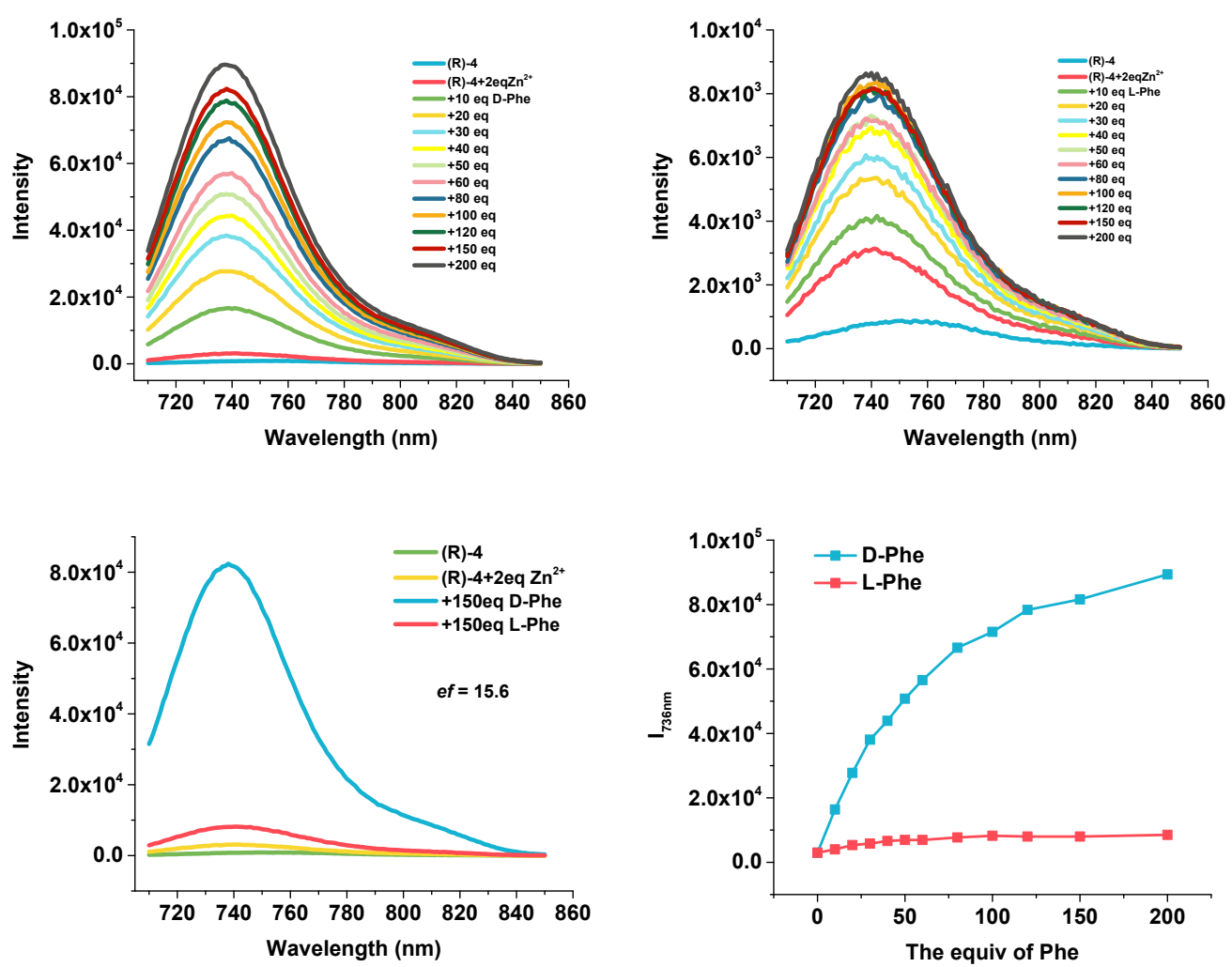
Figure S15. Fluorescence spectra of $(R)-4(10 \mu \mathrm{M})+\mathrm{Zn}^{2+}$ (2 equiv) with various equiv of D-Ser or L-Ser in $50 \mathrm{mM}$ HEPES $(\mathrm{pH}=7.4) / 1 \%$ DMSO. Fluorescence intensity at $736 \mathrm{~nm}$ versus the equiv of Serine. Spectra were recorded at $\mathrm{rt}$ after mixing at $37^{\circ} \mathrm{C}$ for $4 \mathrm{~h} .\left(\lambda_{\mathrm{exc}}=690 \mathrm{~nm}\right.$, slits $\left.=5 / 5 \mathrm{~nm}\right)$
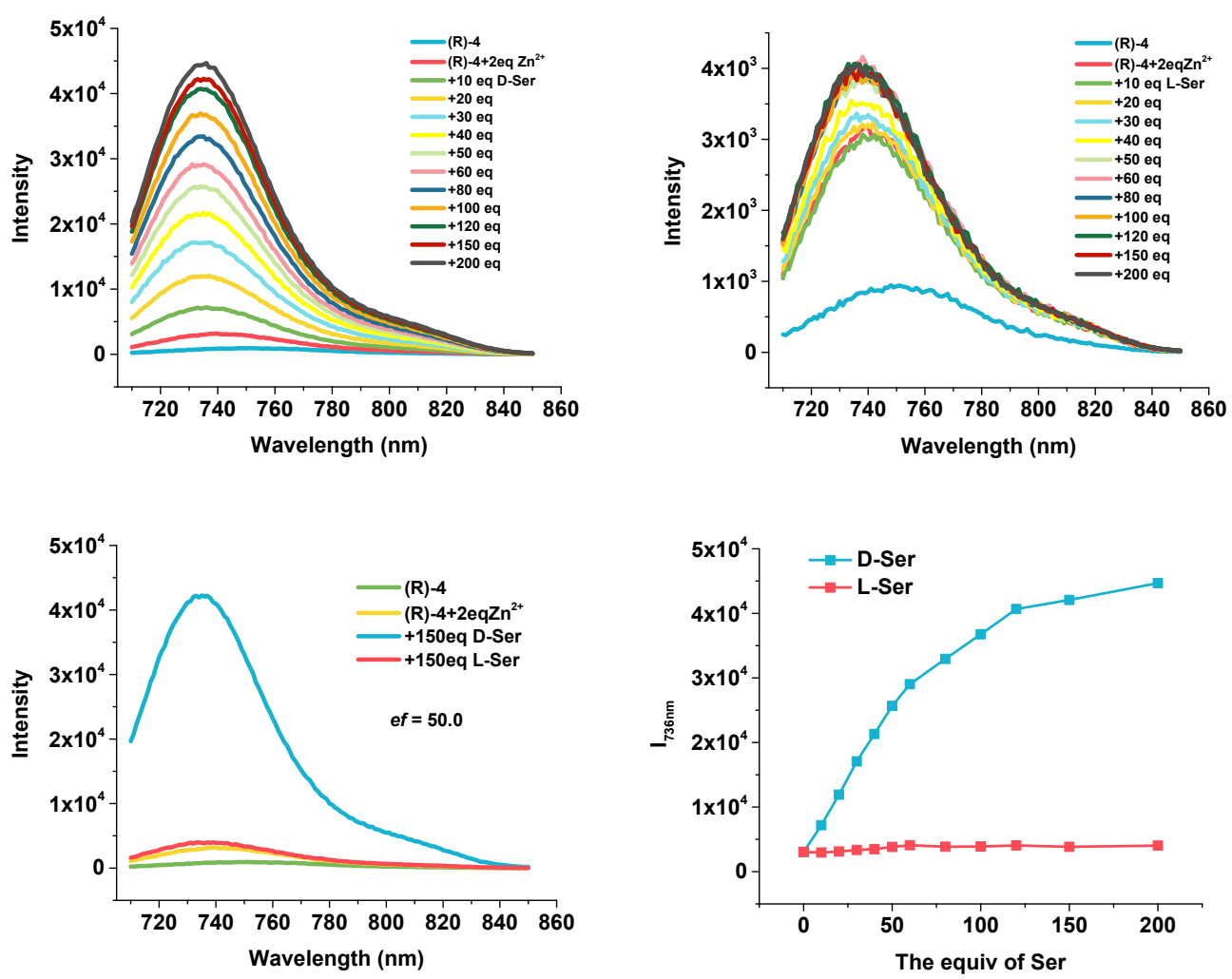
Figure S16. Fluorescence spectra of $(R)-4(10 \mu \mathrm{M})+\mathrm{Zn}^{2+}$ (2 equiv.) with various equiv of D-Thr or L-Thr in $50 \mathrm{mM}$ HEPES $(\mathrm{pH}=7.4) / 1 \%$ DMSO. Fluorescence intensity at $736 \mathrm{~nm}$ versus the equiv of Threonine. Spectra were recorded at $\mathrm{rt}$ after mixing at $37^{\circ} \mathrm{C}$ for $4 \mathrm{~h} .\left(\lambda_{\mathrm{exc}}=690 \mathrm{~nm}\right.$, slits $\left.=5 / 5 \mathrm{~nm}\right)$
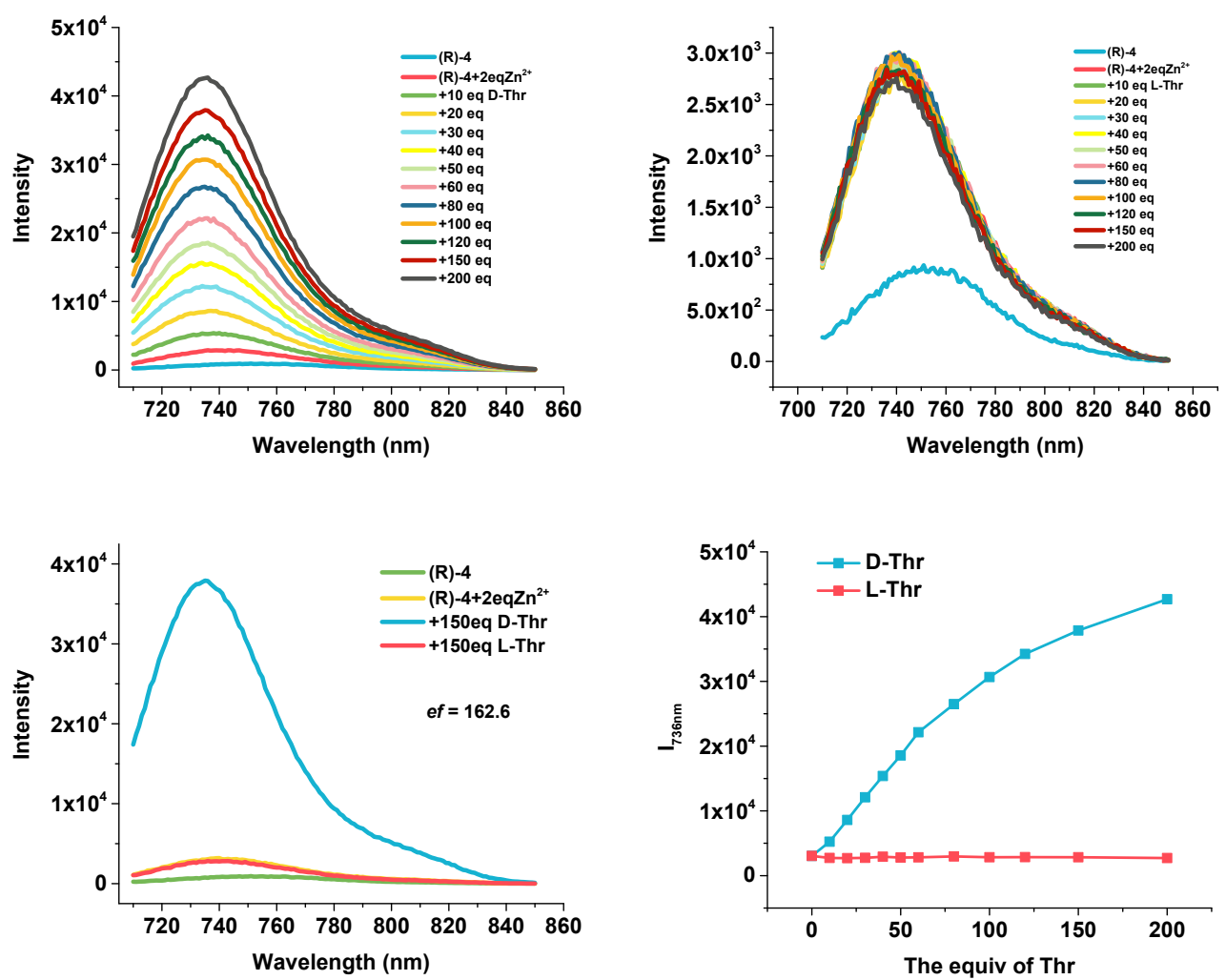
Figure S17. Fluorescence spectra of $(R)-4(10 \mu \mathrm{M})+\mathrm{Zn}^{2+}$ (2 equiv) with various equiv of D-Trp or L-Trp in $50 \mathrm{mM}$ HEPES $(\mathrm{pH}=7.4) / 1 \%$ DMSO. Fluorescence intensity at $736 \mathrm{~nm}$ versus the equiv of tryptophan. Spectra were recorded at $\mathrm{rt}$ after mixing at $37^{\circ} \mathrm{C}$ for $4 \mathrm{~h} .\left(\lambda_{\mathrm{exc}}=690 \mathrm{~nm}\right.$, slits $\left.=5 / 5 \mathrm{~nm}\right)$
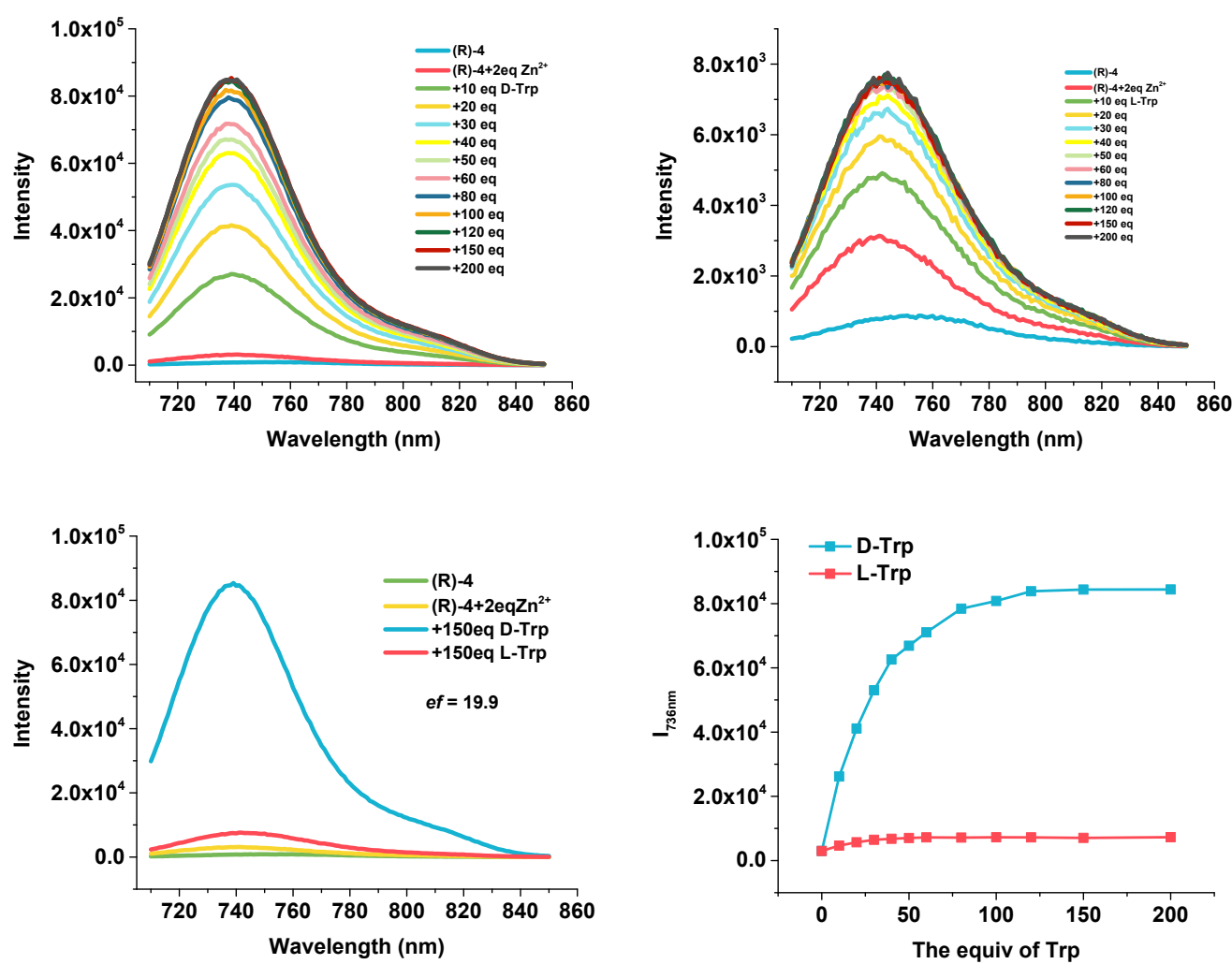
Figure S18. Fluorescence spectra of $(R)-4(10 \mu \mathrm{M})+\mathrm{Zn}^{2+}$ (2 equiv) with various equiv of D-Tyr or L-Tyr in $50 \mathrm{mM}$ HEPES $(\mathrm{pH}=7.4) / 1 \%$ DMSO. Fluorescence intensity at $736 \mathrm{~nm}$ versus the equiv of tyrosine. Spectra were recorded at $\mathrm{rt}$ after mixing at $37^{\circ} \mathrm{C}$ for $4 \mathrm{~h} .\left(\lambda_{\mathrm{exc}}=690 \mathrm{~nm}\right.$, slits $\left.=5 / 5 \mathrm{~nm}\right)$
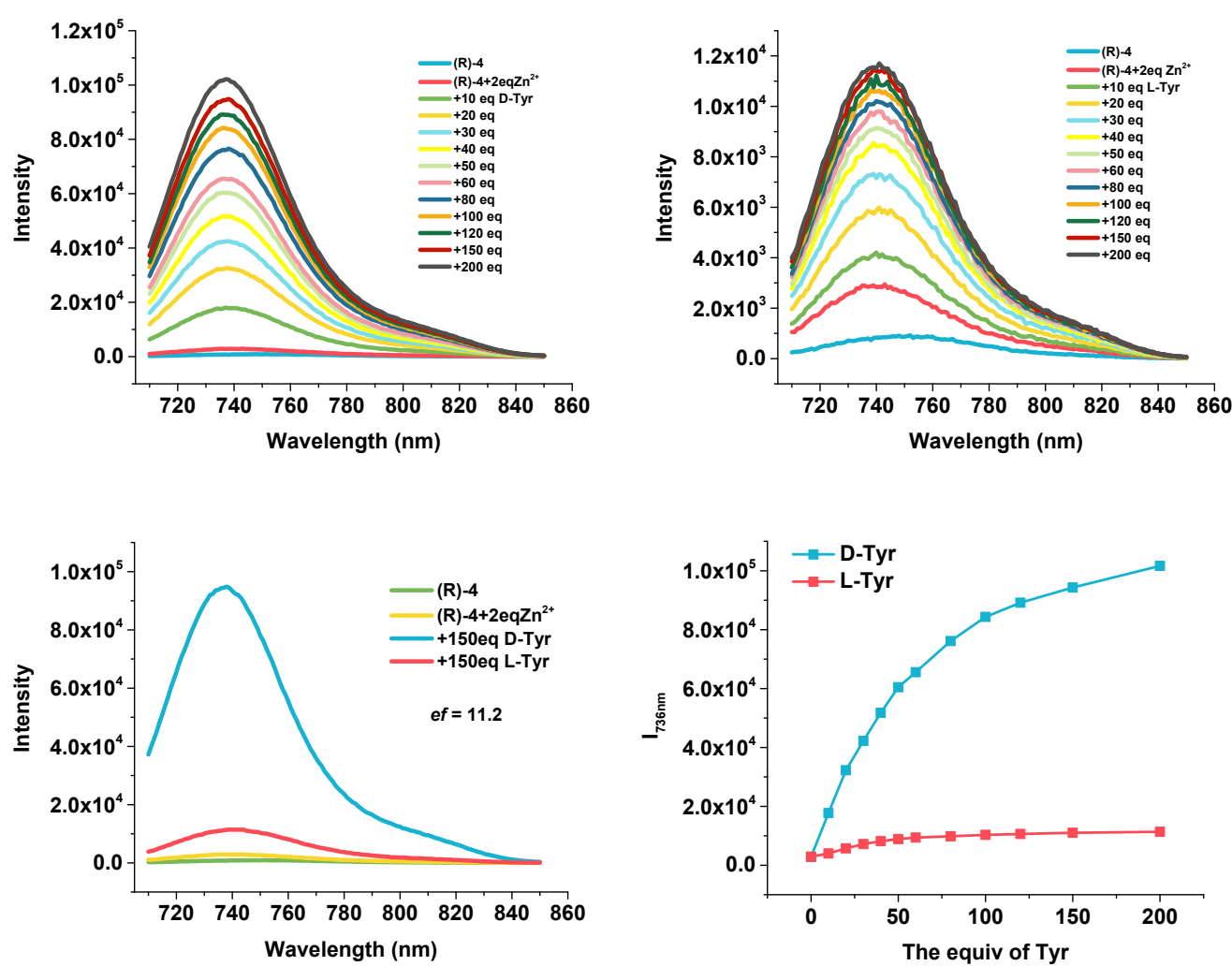
Figure S19. Fluorescence spectra of $(R)-4(10 \mu \mathrm{M})+\mathrm{Zn}^{2+}$ (2 equiv) with various equiv of D-Val or L-Val in $50 \mathrm{mM}$ HEPES $(\mathrm{pH}=7.4) / 1 \%$ DMSO. Fluorescence intensity at $736 \mathrm{~nm}$ versus the equiv of valine. Spectra were recorded at rt after mixing at $37{ }^{\circ} \mathrm{C}$ for $4 \mathrm{~h} .\left(\lambda_{\text {exc }}=690 \mathrm{~nm}\right.$, slits $\left.=5 / 5 \mathrm{~nm}\right)$
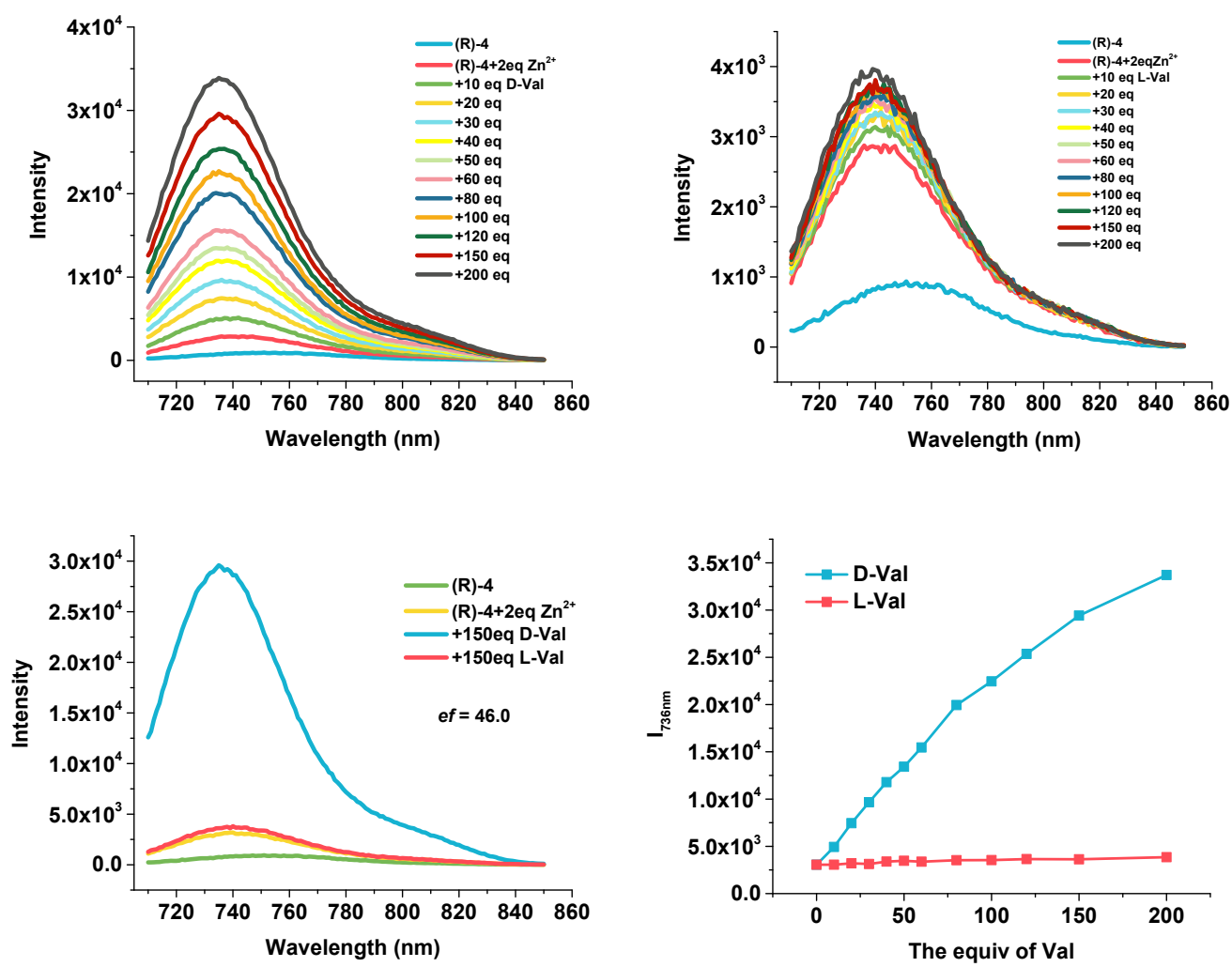


\section{NMR and Mass spectroscopic studies of the reactions}

Figure S20. ${ }^{1} \mathrm{H}$ NMR $(600 \mathrm{MHz})$ titration of $(R)-4(4 \mathrm{mM})+\mathrm{ZnBr}_{2}$ (1 equiv) with D- Met or L-Met in DMSO- $d_{6}$ :HEPES buffer $(3: 1)$ (The ${ }^{1} \mathrm{H}$ NMR spectra were taken after the solution was allowed to stand at room temperature for $4 \mathrm{~h}$. HEPES buffer: $50 \mathrm{mM}$ at $\mathrm{pD}=7.4$ made with $\mathrm{D}_{2} \mathrm{O}$ ).
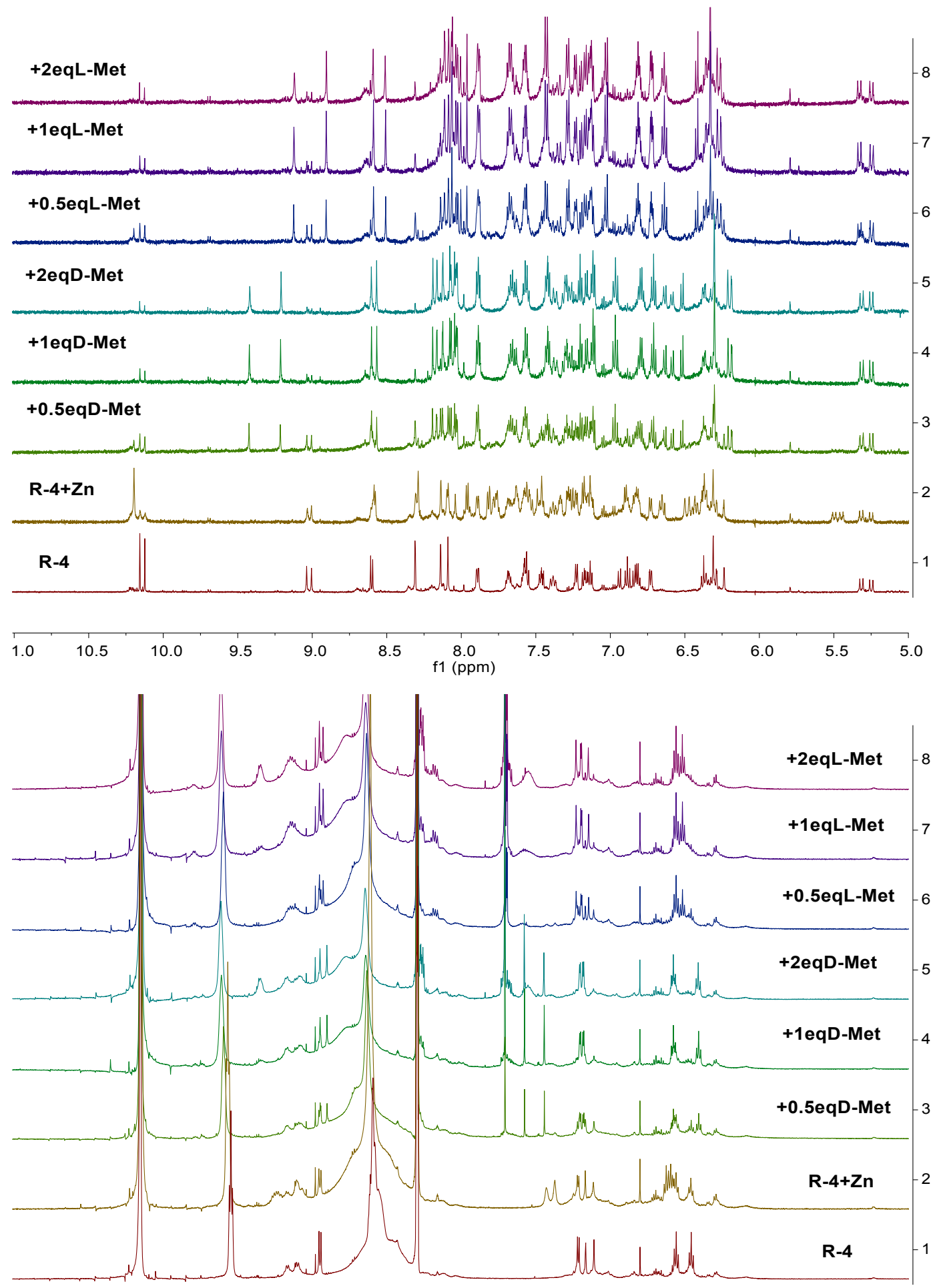

$\begin{array}{lllllllllllllllllllllllllllllllllll}4.8 & 4.6 & 4.4 & 4.2 & 4.0 & 3.8 & 3.6 & 3.4 & 3.2 & 3.0 & 2.8 & 2.6 & 2.4 & 2.2 & 2.0 & 1.8 & 1.6 & 1.4 & 1.2 & 1.0 & 0.8 & 0.6 & 0.4 & 0.2 & 0.0 & -0.2\end{array}$ f1 (ppm) 
Figure S21. TOF mass spectra of $(R)-\mathbf{4}\left(2.0 \times 10^{-5} \mathrm{M}\right)+\mathrm{Zn}(\mathrm{OAc})_{2}(2$ equiv $)+\mathrm{D}-$ Met (150 equiv).

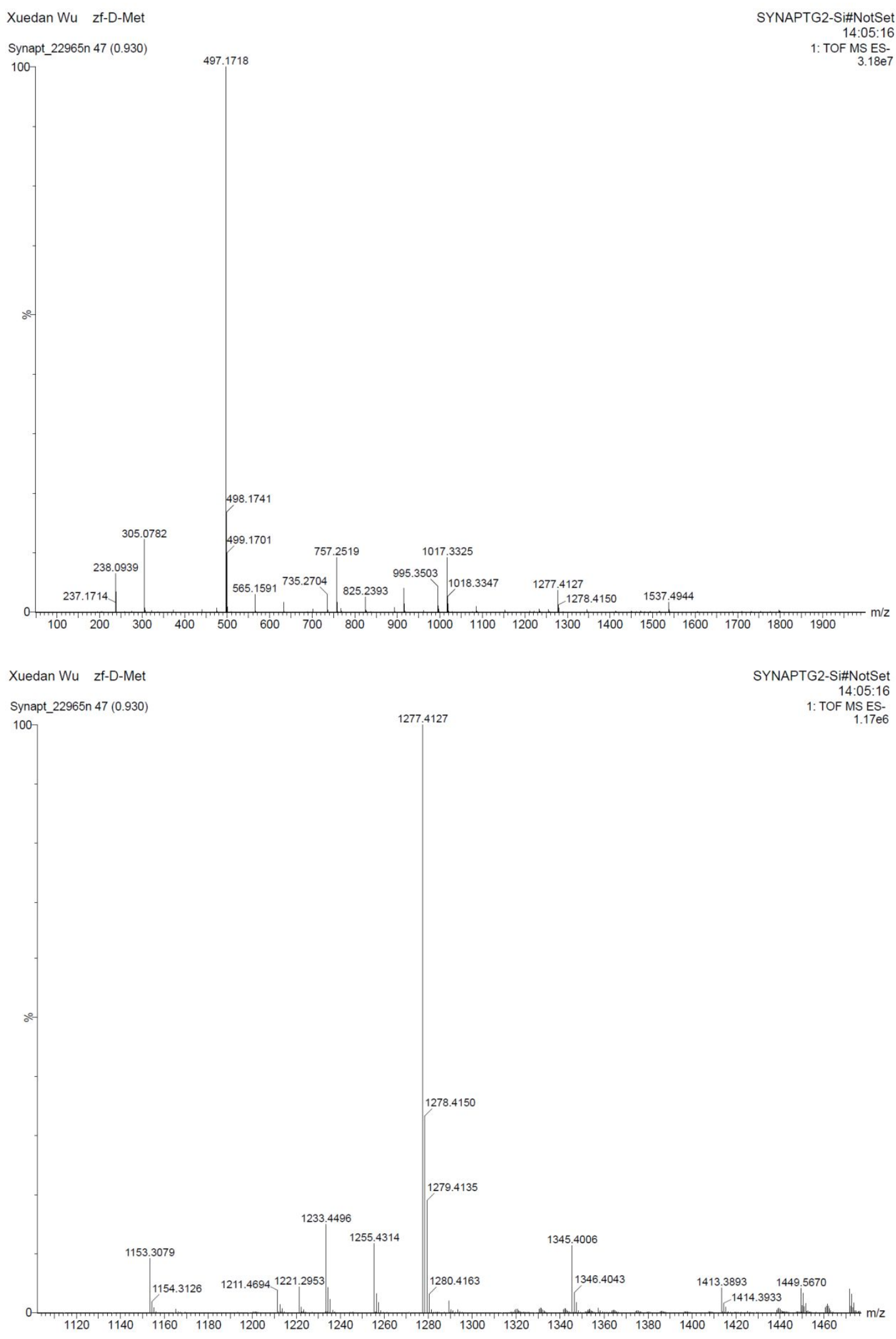


Figure S22. TOF mass spectra of $(R)-\mathbf{4}\left(2.0 \times 10^{-5} \mathrm{M}\right)+\mathrm{Zn}(\mathrm{OAc})_{2}(2$ equiv $)+\mathrm{L}-$ Met (150 equiv).

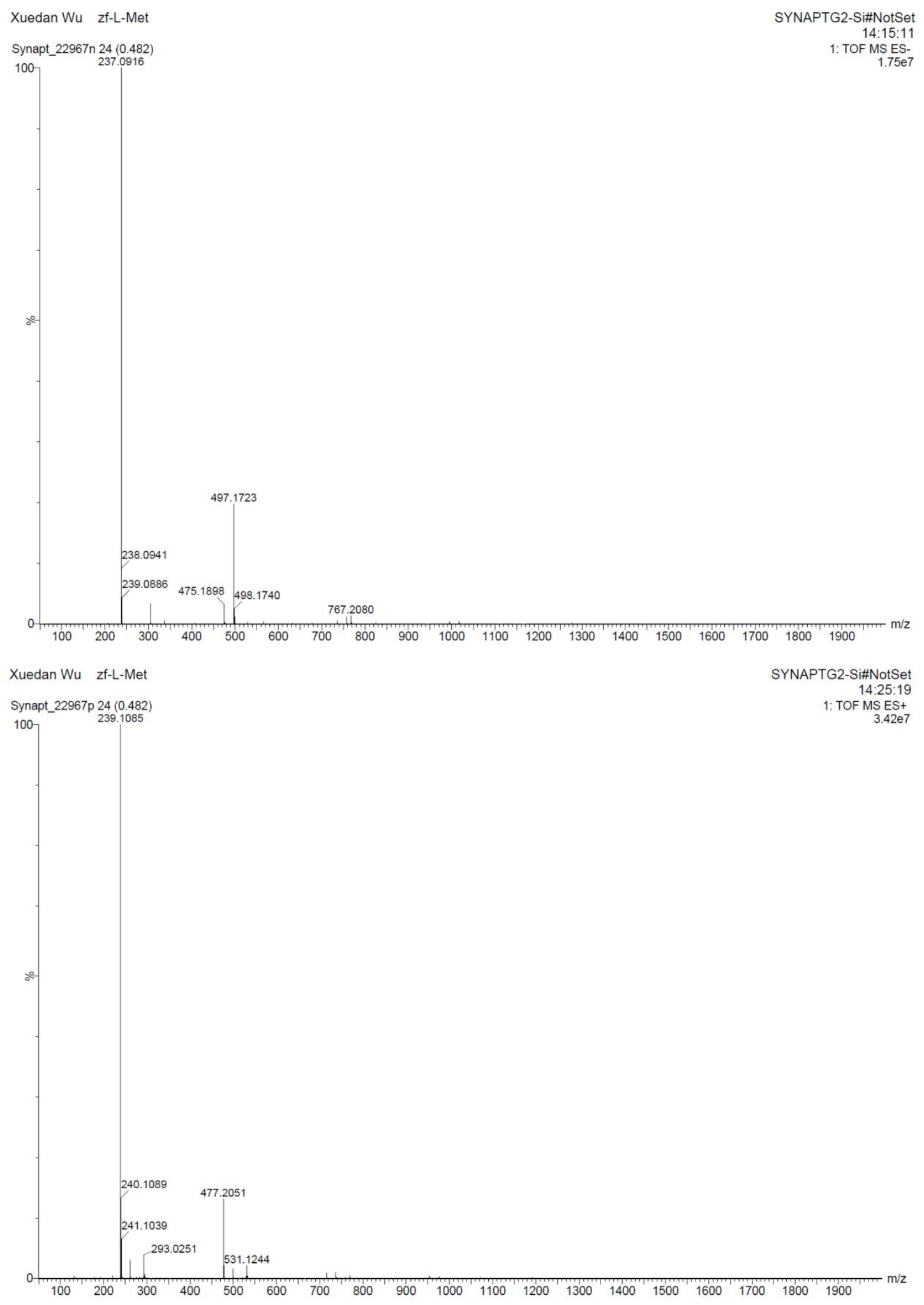




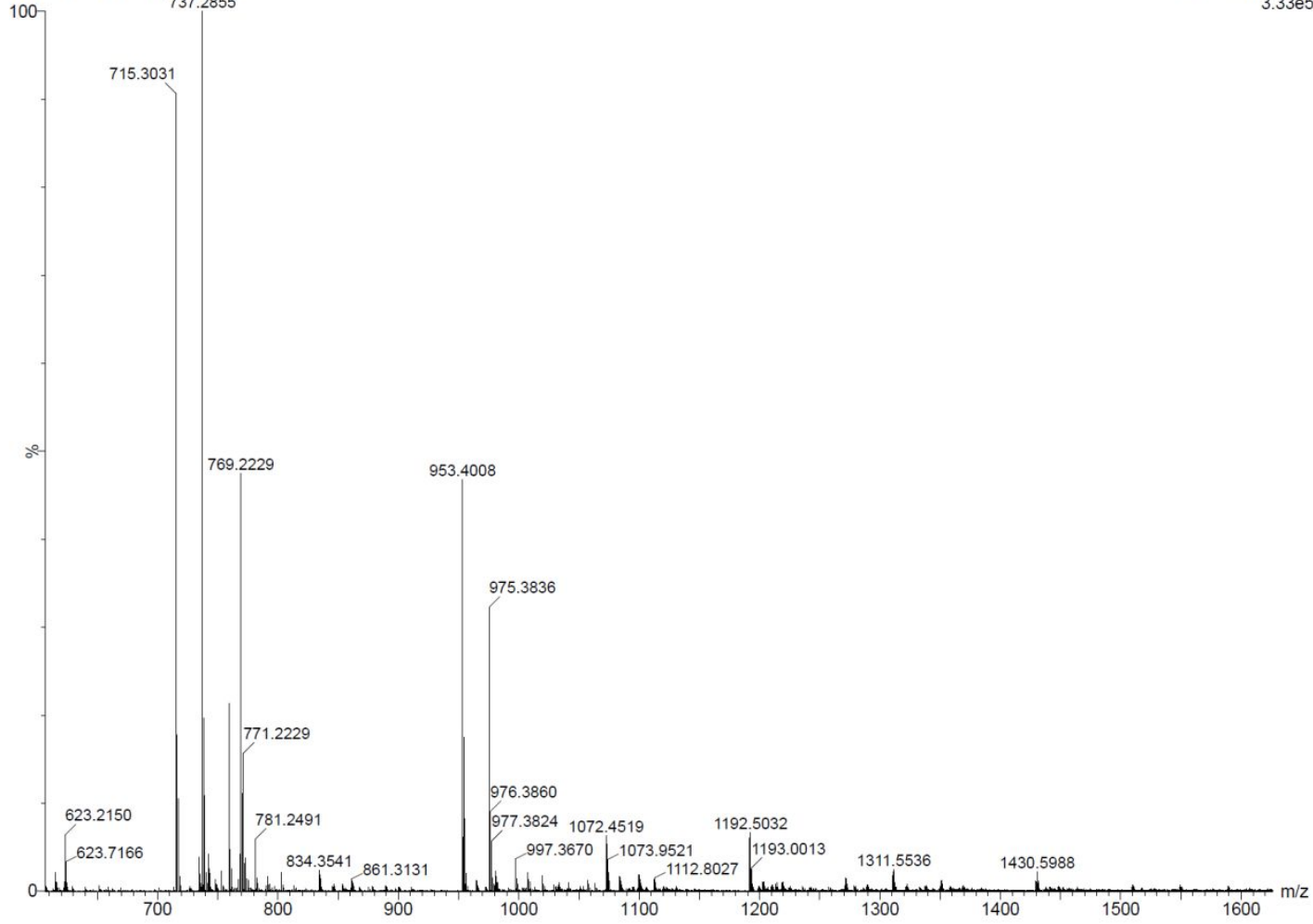


5. Photographs of $(R)-4$ and $\mathrm{ZnBr}_{2}$ with $\mathrm{D}$ - or $\mathrm{L}$-amino acids

Figure S23. Photographs (in room light) of $(R)-4(1 \mathrm{mM})+\mathrm{ZnBr}_{2}$ (1 equiv) with 1 equiv. of D- or L-amino acids in DMSO: HEPES buffer (3: 1).
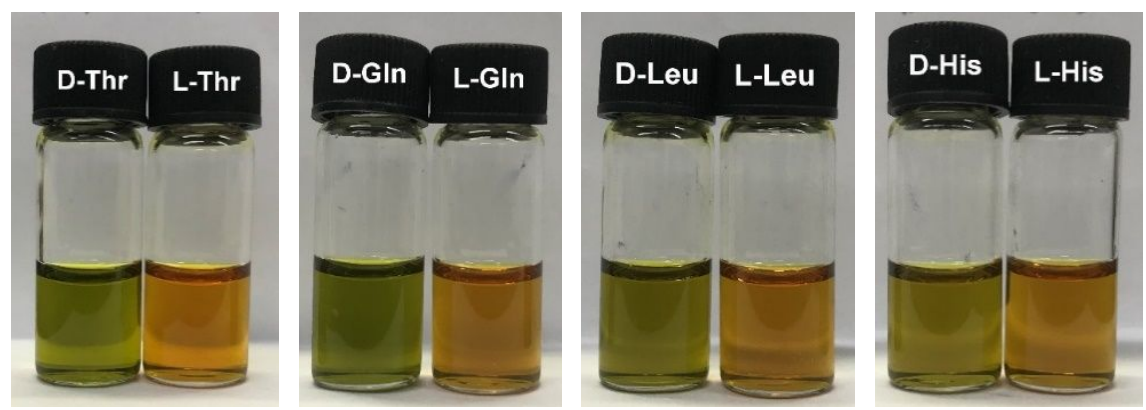
6. Fluorescence spectra of $(R)-4$ with D-Met or $\mathrm{L}-M e t$ in the presence of $\mathrm{Zn}^{2+}$ salts of various counter anions

Figure S24. Fluorescence spectra of $(R)-4\left(1.0 \times 10^{-5} \mathrm{M}\right)$ with several $\mathrm{Zn}^{2+}$ salts in 50 $\mathrm{mM}$ HEPES buffer $(\mathrm{pH}=7.4) / 1 \%$ DMSO in the presence of 150 equiv of D-Met or LMet. Spectra were recorded at $\mathrm{rt}$ after mixing at $37{ }^{\circ} \mathrm{C}$ for $4 \mathrm{~h} . \quad\left(\lambda_{\text {exc }}=690 \mathrm{~nm}\right.$, slits $=$ $5 / 5 \mathrm{~nm}$, recorded on Hitech F-7000 spectrofluorometer).
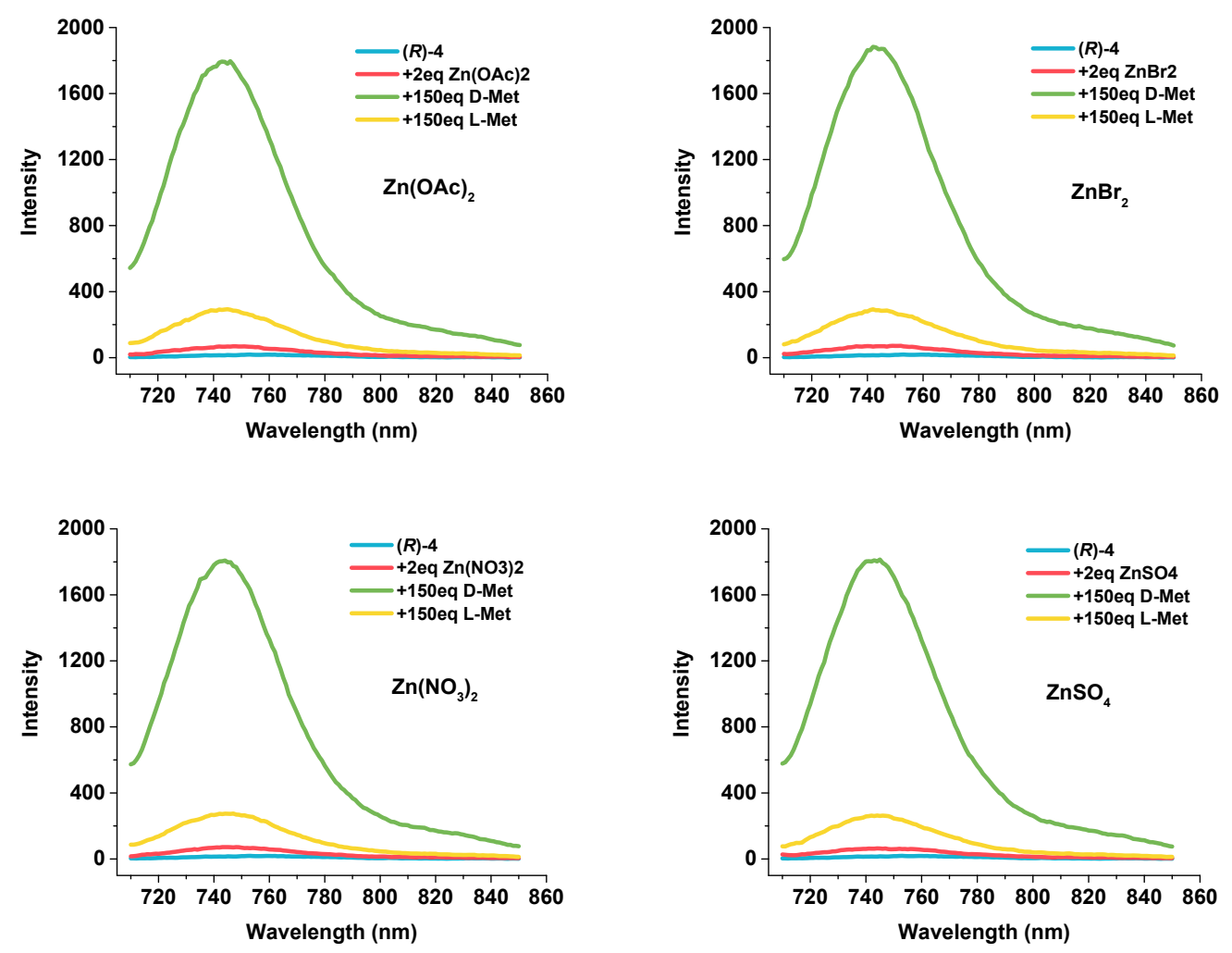